\title{
Adsorption of ethanol onto parent and surface treated activated carbon powders
}

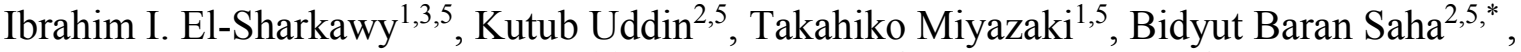 \\ Shigeru Koyama ${ }^{1,2,5}$, Jin Miyawaki ${ }^{4}$, Seong-Ho Yoon ${ }^{4}$ \\ ${ }^{1}$ Faculty of Engineering Sciences, Kyushu University \\ Kasuga-koen 6-1, Kasuga-shi, Fukuoka 816-8580, Japan \\ ${ }^{2}$ Interdisciplinary Graduate School of Engineering Sciences, Kyushu University \\ Kasuga-koen 6-1, Kasuga-shi, Fukuoka 816-8580, Japan \\ ${ }^{3}$ Mechanical Power Engineering Department, Faculty of Engineering \\ Mansoura University, El-Mansoura 35516, Egypt \\ ${ }^{4}$ Institute for Materials Chemistry and Engineering, Kyushu University \\ Kasuga-koen 6-1, Kasuga-shi, Fukuoka 816-8580, Japan \\ ${ }^{5}$ International Institute for Carbon-Neutral Energy Research (WPI-I2CNER), Kyushu University, \\ 744 Motooka, Nishi-ku, Fukuoka 819-0395, Japan \\ *Author to whom correspondence should be addressed, E-mail: \\ saha.baran.bidyut.213@m.kyushu-u.ac.jp
}

\begin{abstract}
:
In this paper, adsorption isotherms and kinetics of ethanol onto highly porous activated carbon powders have been investigated. Adsorbents used in the present study are (i) parent Maxsorb III, (ii) $\mathrm{KOH}-\mathrm{H}_{2}$ treated Maxsorb III, and (iii) $\mathrm{H}_{2}$ treated Maxsorb III. Adsorption isotherms and kinetics of the assorted pairs have been measured using magnetic suspension adsorption measurement unit (MSB-VG-S2). Experiments have been conducted across assorted adsorption temperatures that are useful for the operation of adsorption chillers. The Dubinin-Astakhov equation is used to fit adsorption isotherms of parent Maxsorb III/ethanol and $\mathrm{KOH}-\mathrm{H}_{2}$ treated
\end{abstract}


Maxsorb III pairs whilst the Dubinin-Raduskevich isotherm model is found to be more suitable for fitting of adsorption uptake of $\mathrm{H}_{2}$-treated Maxsorb III/ethanol pair. Adsorption kinetics of assorted pairs are presented by the Fickian diffusion model. Experimental results show that, among the assorted pairs, $\mathrm{H}_{2}$ treated Maxsorb III/ethanol pair possesses the highest adsorption equilibrium uptake. However, the diffusion time constant of $\mathrm{KOH}-\mathrm{H}_{2}$ treated Maxsorb III is found to be higher than that of other two studied pairs.

Key words: Activated carbon; adsorption characteristics; cooling; ethanol

\section{Nomenclature}
A adsorption potential $\left(\mathrm{kJ} \mathrm{Kg}^{-1}\right)$
D diffusivity $\left(\mathrm{m}^{2} \mathrm{~s}^{-1}\right)$
$\mathrm{D}_{\text {so }} \quad$ pre-exponential constant $\left(\mathrm{m}^{2} \mathrm{~s}^{-1}\right)$
E adsorption characteristics parameter $\left(\mathrm{kJ} \mathrm{Kg}^{-1}\right)$
Ea activation energy $\left(\mathrm{kJ} \mathrm{kg}^{-1}\right)$
F fractional uptake (-)
$\mathrm{P} \quad$ equilibrium pressure $(\mathrm{kPa})$
$\mathrm{Ps}_{\mathrm{s}} \quad$ saturated pressure $(\mathrm{kPa})$
$\mathrm{Rg}$ gas constant $\left(\mathrm{kJ} \mathrm{kg}^{-1} \mathrm{~K}^{-1}\right)$
$\mathrm{R}_{\mathrm{p}} \quad$ particle radius $(\mu \mathrm{m})$
$\mathrm{T}$ temperature $(\mathrm{K})$
t time (s) 


$$
\begin{aligned}
& \text { W equilibrium adsorption uptake }\left(\mathrm{kg} \mathrm{kg}^{-1}\right) \\
& \text { W } \quad \text { instantaneous adsorption uptake }\left(\mathrm{kg} \mathrm{kg}^{-1}\right) \\
& \text { Win } \quad \text { initial uptake }\left(\mathrm{kg} \mathrm{kg}^{-1}\right) \\
& \mathrm{W}_{\mathrm{o}} \quad \text { maximum adsorption capacity }\left(\mathrm{kg} \mathrm{kg}^{-1}\right)
\end{aligned}
$$

\section{Introduction}

The decade of 1930s witnessed a revolution in cooling technology with the development of Freon type synthesis refrigerants, which greatly increased the coefficient of performance of vapor compression based systems. However, synthetic refrigerant based vapor compression systems have two major concerns. The substances such as CFCs, HCFCs, etc. which are used as the working fluid in most vapor compression systems have been found to be responsible for Ozone layer depletion as well as contributing to global warming. Moreover, vapor compression systems use compressors that consume huge amount of electrical energy. The need for a switch over to green and sustainable alternatives is, thus, evermore pressing. Thermally powered adsorption cooling system is considered one of the most promising alternatives of electricity powered vapor compression system. Design of efficient adsorption cooling systems requires accurate information about adsorption characteristics of adsorbent/refrigerant pairs. Among these characteristics, adsorption isotherms and kinetics play essential rules on the system design and performance optimization. Extensive research efforts have been conducted to investigate adsorption isotherms of various adsorbent/refrigerant pairs [1-7]. Adsorption kinetics has also been addressed by a notable number of researchers, following are some representative examples. Aristov et al. [8] measured adsorption kinetics of water vapor on loose grains of Fuji Davison 
RD silica gel using TG differential method. Experiments have conducted within a temperature range of $29-64{ }^{\circ} \mathrm{C}$ and a pressure range from 6.5 to 34 mbar. Adsorption kinetics of water on to composite material $\left(\mathrm{CaCl}_{2}\right.$ confined to mesoporous silica named SWS-1L) has also been investigated using a CAHN microbalance under isothermal conditions at constant pressure [9]. Three different grain sizes of SWS-1L have been tested and results showed a remarkable enhancement in adsorption rate with the decrease in particle size. El-Sharkawy et al. [10] investigated adsorption kinetics of activated carbon fiber/ethanol pair by gravimetric method using TGA (CAHN TG 2121) unit. The authors proposed a new concentration profile that removes the restrictions between the overall mass transfer coefficient and the diffusion time constant and the model has been validated experimentally. Adsorption kinetics of ammonia onto composite adsorbent material $\left(\mathrm{BaCl}_{2}\right.$ impregnated into a vermiculite matrix) has been investigated under isothermal conditions and in a laboratory scale system [11]. Veselovskaya et al. [12] measured adsorption kinetics of the same pairs under conditions more close to the real conditions of adsorption chillers. The authors reported that this material can provide a COP as high as $0.54 \pm 0.01$ and SCP ranging from 300 to $680 \mathrm{~W} / \mathrm{kg}$ using heat source temperatures between $80-90{ }^{\circ} \mathrm{C}$. Dawoud and Aristov [13] measured adsorption kinetics of water vapor sorption on mesoporous silica gel, alumina, microporous silica gel and two composites, namely SWS-1L and SWS-1A. These composite materials are formed by impregnating $\mathrm{CaCl}_{2}$ into mesoporous silica gel and alumina, respectively. The authors reported that there is an increase of about two to three times in the differential water loading on the SWS-composites compared to the host materials. However, the kinetics of water sorption into the host matrices is faster than that into the studied two SWS-composites. Aristov [14] discussed principles of creating 
database of adsorbents promising for adsorptive transformation of heat. The proposed database considered the main adsorbent properties and addresses the issues of their measurement and calculation. The study also presented a tentative list of promising adsorbent-adsorbate pairs. Other studies dealing with adsorption kinetics can be found elsewhere [15-19].

The present study deals with experimental investigation of adsorption isotherms and kinetics of ethanol onto three types of adsorbents namely; parent Maxsorb III, $\mathrm{KOH}-\mathrm{H}_{2}$ treated Maxsorb III and $\mathrm{H}_{2}$ treated Maxsorb III. Experimental measurements have been conducted using a magnetic suspension balance. Experiments have been conducted across assorted adsorption temperatures that are useful for the operation of adsorption chillers. The Dubinin-Astakhov and the DubininRaduskevich equations are used to fit the equilibrium uptake whilst adsorption kinetics are correlated using the Fickian diffusion model.

\section{Experimental section}

\subsection{Materials}

The adsorbents used in the present study are; (i) Parent Maxsorb III which is a highly porous activated carbon powder provided by Kansai Coke \& Chemicals Co. Ltd., Japan (ii) a surface treated Maxsorb III (KOH-H${ }_{2}$ Maxsorb III), and (iii) $\mathrm{H}_{2}$-surafce treated Maxsorb III. The treatment procedure has been described in reference [20]. Thermo-physical properties and elemental composition of assorted adsorbents are given in Table 1 and 2, respectively. It can be seen from Table 1 that, there is no significant change in both surface area and average pore width. However, $\mathrm{H}_{2}$-traeted Maxsorb III possesses the highest micropore volume followed by parent Maxsorb III then $\mathrm{KOH}-\mathrm{H}_{2}$ - treated Maxsorb III. As can be seen from Table 2, oxygen 
contents increases significantly for $\mathrm{KOH}-\mathrm{H}_{2}-\mathrm{Maxsorb}$ III whilst $\mathrm{H}_{2}$-treated Maxsorb III has the lowest oxygen content among assorted adsorbents.

The particle size distribution is measured using a Laser Diffraction Particle Size Analyzer, SALD-2300, supplied by Shimadzu Corporation, Japan. Pictorial view of the apparatus is shown in Fig. 1(a). Particle size distribution is calculated using the light intensity distribution pattern of scattered light that is generated from sample particles when laser irradiates them. The adsorbent sample is mixed with distilled water in the dissipation bath of SALD-2300; it is then circulated through the flow cell in the measuring unit where it is irradiated with a laser beam. Figures 1(b)(d) shows the particle size distributions of parent Maxsorb III, $\mathrm{KOH}-\mathrm{H}_{2}$ treated Maxsorb III and $\mathrm{H}_{2}$ treated Maxsorb III. It can be seen that the percentage of cumulative normalized particle amount reaches a value of 50\% at particle diameters of 105, 100 and $107 \mu \mathrm{m}$ for parent Maxsorb III, $\mathrm{KOH}-\mathrm{H}_{2}$ treated Maxsorb III and $\mathrm{H}_{2}$ treated Maxsorb III, respectively. Ethanol of $99.5 \%$ purity supplied by Osaka Kishida Chemical Co., Ltd is used as adsorbate in the present study.

\subsection{Procedure}

In the present study, adsorption isotherms and kinetics of assorted adsorbent/refrigerant pairs are measured gravimetrically using magnetic suspension adsorption measurement unit (Rubotherm of type MSB-VG-S2) supplied by BEL Japan, Inc. Fig. 2 shows the schematic diagram of the magnetic suspension adsorption measurement unit. Experimental procedure can be explained as follows;

(1) An adsorbent sample of $77 \mathrm{mg}$ is placed into the sample basket and placed into the measuring chamber of the magnetic suspension balance unit. 
(2) The sample is regenerated at $120{ }^{\circ} \mathrm{C}$ under vacuum conditions for about 4 hours; the sample is then cooled down to the set adsorption temperature where measuring chamber is disconnected from the vacuum pump units.

(3) The measuring chamber is connected to the evaporator chamber. Evaporator temperature is controlled using an oil bath. Pressure of measuring chamber increases rapidly until it reaches the evaporator pressure corresponding to the set evaporator temperature. Adsorption process is then carried out where adsorbent mass is recorded continuously until reaches to the adsorption equilibrium conditions.

(4) Evaporator is then disconnected from the adsorption chamber where its temperature increases to a certain value to create a new evaporation pressure for the next measuring step.

(5) Steps (2) and (3) are repeated for other sets of adsorption temperatures.

It is worthy to mention that the instantaneous measurement of adsorbent sample is used to investigate adsorption kinetics.

\section{Results and discussion}

\subsection{Adsorption isotherms}

Plots of equilibrium adsorption uptake versus equilibrium pressure of parent Maxsorb III/ethanol, $\mathrm{KOH}-\mathrm{H}_{2}$ treated Maxsorb III/ethanol and $\mathrm{H}_{2}$-treated Maxsorb III/ethanol pairs are presented in Fig. 3(a), (b) and (c), respectively. The Dubinin-Astakhov equation (Eq. 1) is used to fit adsorption isotherms of parent Maxsorb III/ethanol and $\mathrm{KOH}-\mathrm{H}_{2}$ treated Maxsorb III/ethanol pairs whilst the Dubinin-Raduskevich equation (Eq. 2) is found to be more suitable for fitting of 
adsorption uptake of $\mathrm{H}_{2}$-treated Maxsorb III/ethanol pair. Isotherm parameters of the assorted adsorbent/refrigerant pairs are estimated as described by El-Sharkawy et al. [3]. Numerical values of these parameters are furnished in Table 3.

$$
\begin{aligned}
& W=W_{0} \exp \left[-\left(\frac{A}{E}\right)^{n}\right] \\
& W=W_{0} \exp \left[-\left(\frac{A}{E}\right)^{2}\right]
\end{aligned}
$$

Where $\mathrm{A}$ is the adsorption potential and can be estimated using the following relation;

$$
A=R_{g} \ln \left(\frac{P_{s}}{P}\right)
$$

One can notice that $\mathrm{H}_{2}$ treated Maxsorb III has the highest maximum adsorption uptake ( $\left.W_{o}\right)$, followed by parent Maxsorb III and the lowest value is found to be corresponding to $\mathrm{KOH}-\mathrm{H}_{2}$ treated Maxsorb III. This order agrees with the order of micro-pore volume of the assorted adsorbents keeping in mind that all adsorbents have nearly the same surface area. It is also worthy to mention that the numerical value of adsorption characteristics $E$ of parent Maxsorb III/ethanol pair is slightly higher than that presented by El-Sharkawy et al. [21] . This is because, in the present study, adsorption uptake is measured at different evaporation pressures at each isotherm where the relative pressure varies between 0.1 to about 0.8 employing the multi-step technique whilst adsorption uptake measured in the previous study was conducted at a single evaporation pressure. 


\subsection{Adsorption kinetics}

Temporal histories of adsorption uptake and pressure of parent Maxsorb III/ethanol pair for adsorption temperatures of 30 and $70{ }^{\circ} \mathrm{C}$ are shown in Figs. 4(a) and 4(b), respectively. At each adsorption step, adsorption uptake increases continuously until reaches the equilibrium condition corresponding to adsorption temperature and evaporator pressure. Similar plots of adsorption uptake and pressure versus time at adsorption temperature of $30{ }^{\circ} \mathrm{C}$ for both $\mathrm{KOH}-\mathrm{H}_{2}$ treated Maxsorb III/ethanol and $\mathrm{H}_{2}$-treated Maxsorb III/ethanol pairs are depicted in Figs. 5 and 6, respectively.

The Fickian diffusion model is used to estimate the adsorptions kinetics of assorted adsorbent/refrigerant pairs. Considering a spherical adsorbent particle shape, adsorption rate can be estimated using the diffusion equation (Eq. 4) as follows [22];

$\frac{\partial w}{\partial t}=\frac{1}{r^{2}} \frac{\partial}{\partial r}\left(r^{2} D \frac{\partial w}{\partial r}\right)$

Solution of equation (4) is given the familiar expression (Eq. 5) below [23];

$$
F=\frac{w-w_{i n}}{W-w_{i n}}=1-\frac{6}{\pi^{2}} \sum_{n=1}^{\infty} \frac{1}{n^{2}} \exp \left(-\frac{n^{2} \pi^{2} D t}{R_{p}^{2}}\right)
$$

where $R_{p}$ is the particle radius of adsorbent. 
The expression given in Eq. (5) converges rapidly in the long time region science the higher terms of the summation become vanishingly small [22]. Equation (5) can be then simplified to equation to Eq. (6) at longer times;

$$
F=\frac{w-w_{i n}}{W-w_{i n}}=1-\frac{6}{\pi^{2}} \exp \left(-\frac{\pi^{2} D t}{R_{p}^{2}}\right)
$$

The linearization of Eq. (6) gives;

$$
\ln (1-F)=\ln \left(\frac{6}{\pi^{2}}\right)-\pi^{2}\left(\frac{D}{R_{p}^{2}}\right) t
$$

The linear plots of $\ln (1-F)$ versus time allows the evaluation of the diffusional time constant $\left(D / R_{p}^{2}\right)[22,24-26]$. Figures 7(a) and (b) show plots of $\ln (1-F)$ versus time for parent Maxsorb III/ethanol pair at adsorption temperatures of 30 and $70{ }^{\circ} \mathrm{C}$ and certain evaporation pressures. It can be seen that the diffusional time constant can be estimated with high accuracy. It is also worth mentioning that, evaluation of $\left(\mathrm{D} / \mathrm{R}_{\mathrm{p}}{ }^{2}\right)$ using this technique avoids the uncertainties in adsorption uptake measurements in the early stage of adsorption. Moreover, this technique helps to overcome the effects of generation of heat of adsorption at early stage of adsorption. The same plots for $\mathrm{KOH}-\mathrm{H}_{2}$ treated Maxsorb III/ethanol and $\mathrm{H}_{2}$ treated Maxsorb III/ethanol pairs at $30{ }^{\circ} \mathrm{C}$ adsorption temperature are shown in Fig. 8 and Fig. 9, respectively. Experimental fractional uptake and that predicted using the Fickian diffusion model for parent Maxsorb III/ethanol, KOH- $\mathrm{H}_{2}$ treated Maxsorb III/ethanol and $\mathrm{H}_{2}$ treated Maxsorb III/ethanol pairs are shown in Figs. 10(a)-(c). 
Diffusion time constant at each pressure step for parent Maxsorb III/ethanol, $\mathrm{KOH}-\mathrm{H}_{2}$ treated Maxsorb III/ethanol and $\mathrm{H}_{2}$ treated Maxsorb III/ethanol pairs are presented, respectively, in Tables 4, 5 and 6. It can be seen that the differential time constant of $\mathrm{KOH}-\mathrm{H}_{2}$ treated Maxsorb III/ethanol pair is higher than that of the other two studied pairs which leads to a faster adsorption kinetics. This can be explained as follows, the polar ethanol molecules is quickly attached and adsorbed by the functionalities nearby the surface through hydrogen bonds, which causes faster adsorption rate. Figure 11 shows plots of diffusion time constant versus equilibrium pressure for the assorted pairs at adsorption temperature of $50{ }^{\circ} \mathrm{C}$. It can be seen that the diffusion time constant of the studied pairs is high at the low equilibrium pressure. However, it dresses to reach a minimal value at pressure around $3 \mathrm{kPa}$ and then slightly increases with relatively higher pressures. The same trend is also observed by some other researchers for other adsorbent/refrigerant pairs [9].

The average values of diffusion adsorption kinetics at each temperature is calculated and a plot of $\ln \left(D / R_{p}{ }^{2}\right)$ versus the inverse of adsorption temperature (1/T) is shown in Fig. 12 for all three studied pairs. It can be seen from Fig. 12 that the relationship between $\ln \left(D / R_{p}^{2}\right)$ and $(1 / T)$ follows the usual trend of classical Arrhenius equation (Eq. 8).

$D=D_{\text {so }} \exp \left(\frac{-E_{a}}{R_{g} T}\right)$

Dividing both sides of Eq. (8) by $R_{p}^{2}$, the linearization of this equation gives;

$$
\ln \left(\frac{D}{R_{p}^{2}}\right)=-\ln \left(\frac{D_{s 0}}{R_{p}^{2}}\right)-\left(\frac{E_{a}}{R_{g}}\right)\left(\frac{1}{T}\right)
$$


Numerical values of the pre-exponential constant $\left(D_{s o} / R_{p}^{2}\right)$ and activation energy $\left(E_{a}\right)$ of assorted pairs are furnished in Table 7. It can be observed from Table 7 that the $\mathrm{KOH}-\mathrm{H}_{2}$ treated Maxsorb III/ethanol pair has the highest activation energy among the three studied pairs. This is might be due to the hydrogen bonds that formed between polar ethanol molecules and the functionalities nearby the adsorbent surface. It can be seen from Figs. 1(b)-(d) that parent Maxsorb III, KOH-H2 treated and $\mathrm{H}_{2}$ treated Maxsorb III have a wide range of particle size distributions. The large particle size might control adsorption kinetics at the last stage of adsorption time where the linear tail on Figs. 7-9 is observed. Therefore, using the average value of the relatively larger size particles to estimate the numerical values of $D_{\text {so }}$ of the assorted pairs might be a justified assumption. A detailed study of adsorption kinetics using a narrow range of particle size will be considered in another study.

\section{Conclusions}

Adsorption isotherms and kinetics of parent Maxsorb III/ethanol, $\mathrm{KOH}-\mathrm{H}_{2}$ treated Maxsorb III/ethanol and $\mathrm{H}_{2}$ treated Maxsorb III pairs have been measured experimentally using a magnetic suspension adsorption measurement unit. The Dubinin-Astakhov and the Dubinin-Radushkevich equations are used to fit the equilibrium uptake whilst adsorption kinetics is presented by the Fickian diffusion model. Experimental results show that, the maximum adsorption capacity of $\mathrm{H}_{2}$ treated Maxsorb III/ethanol pair is about $1.23 \mathrm{~kg} / \mathrm{kg}$ whilst parent Maxsorb III/ethanol and $\mathrm{KOH}-\mathrm{H}_{2}$ treated Maxsorb III/ethanol has maximum adsorption capacities of $1.2 \mathrm{~kg} / \mathrm{kg}$ and 1.01 $\mathrm{kg} / \mathrm{kg}$, respectively. It is also found that, the Fickian diffusion model can fairly present adsorption kinetics of assorted adsorbent/refrigerant pairs. Adsorption kinetics of ethanol onto 
$\mathrm{KOH}-\mathrm{H}_{2}$ treated Maxsorb III is faster than other two studied adsorbents. Data extracted from the present study are essential in designing high performance thermally powered adsorption chiller and heat pump systems.

\section{Acknowledgements}

This work was financially supported by Japan Science and Technology Agency (JST), Core Research Evolution Science and Technology (CREST). 


\section{References}

[1] Q. Cui, G. Tao, H. Chen, X. Guo, H. Yao, Environmentally benign working pairs for adsorption refrigeration, Energy, 30(2-4) (2005) 261-271.

[2] R.E. Critoph, Evaluation of alternative refrigerant - adsorbent pairs for refrigeration cycles, Applied Thermal Engineering, 16(11) (1996) 891-900.

[3] I.I. El-Sharkawy, K. Kuwahara, B.B. Saha, S. Koyama, K.C. Ng, Experimental investigation of activated carbon fibers/ethanol pairs for adsorption cooling system application, Applied Thermal Engineering, 26(8-9) (2006) 859-865.

[4] I.I. El-Sharkawy, M. Hassan, B.B. Saha, S. Koyama, M.M. Nasr, Study on adsorption of methanol onto carbon based adsorbents, International Journal of Refrigeration, 32(7) (2009) 1579-1586.

[5] İ. Solmuş, C. Yamalı, B. Kaftanoğlu, D. Baker, A. Çağlar, Adsorption properties of a natural zeolite-water pair for use in adsorption cooling cycles, Applied Energy, 87(6) (2010) 2062-2067.

[6] S.K. Henninger, F.P. Schmidt, H.M. Henning, Water adsorption characteristics of novel materials for heat transformation applications, Applied Thermal Engineering, 30(13) (2010) 1692-1702.

[7] B.B. Saha, I.I. El-Sharkawy, R. Thorpe, R.E. Critoph, Accurate adsorption isotherms of R134a onto activated carbons for cooling and freezing applications, International Journal of Refrigeration, 35(3) (2012) 499-505.

[8] Y.I. Aristov, M.M. Tokarev, A. Freni, I.S. Glaznev, G. Restuccia, Kinetics of water adsorption on silica Fuji Davison RD, Microporous and Mesoporous Materials, 96(1-3) (2006) 65-71.

[9] Y.I. Aristov, I.S. Glaznev, A. Freni, G. Restuccia, Kinetics of water sorption on SWS-1L (calcium chloride confined to mesoporous silica gel): Influence of grain size and temperature, Chemical Engineering Science, 61(5) (2006) 1453-1458. 
[10] I.I. El-Sharkawy, B.B. Saha, S. Koyama, K.C. Ng, A study on the kinetics of ethanolactivated carbon fiber: Theory and experiments, International Journal of Heat and Mass Transfer, 49(17-18) (2006) 3104-3110.

[11] Y. Zhong, R.E. Critoph, R.N. Thorpe, Z. Tamainot-Telto, Dynamics of BaCl2-NH3 adsorption pair, Applied Thermal Engineering, 29(5-6) (2009) 1180-1186.

[12] J.V. Veselovskaya, R.E. Critoph, R.N. Thorpe, S. Metcalf, M.M. Tokarev, Y.I. Aristov, Novel ammonia sorbents "porous matrix modified by active salt" for adsorptive heat transformation: 3 . Testing of "BaCl2/vermiculite" composite in a lab-scale adsorption chiller, Applied Thermal Engineering, 30(10) (2010) 1188-1192.

[13] B. Dawoud, Y. Aristov, Experimental study on the kinetics of water vapor sorption on selective water sorbents, silica gel and alumina under typical operating conditions of sorption heat pumps, International Journal of Heat and Mass Transfer, 46(2) (2003) 273-281.

[14] Y.I. Aristov, Adsorptive transformation of heat: Principles of construction of adsorbents database, Applied Thermal Engineering, 42(0) (2012) 18-24.

[15] I.I. El-Sharkawy, On the linear driving force approximation for adsorption cooling applications, International Journal of Refrigeration, 34(3) (2011) 667-673.

[16] A. Rezk, R. Al-Dadah, S. Mahmoud, A. Elsayed, Characterisation of metal organic frameworks for adsorption cooling, International Journal of Heat and Mass Transfer, 55(25-26) (2012) 7366-7374.

[17] B.B. Saha, I.I. El-Sharkawy, A. Chakraborty, S. Koyama, S.H. Yoon, K.C. Ng, Adsorption rate of ethanol on activated carbon fiber, Journal of Chemical and Engineering Data, 51(5) (2006) 1587-1592.

[18] K. Habib, B.B. Saha, K.A. Rahman, A. Chakraborty, S. Koyama, K.C. Ng, Experimental study on adsorption kinetics of activated carbon/R134a and activated carbon/R507A pairs, International Journal of Refrigeration, 33(4) (2010) 706-713. 
[19] B. Dawoud, Water vapor adsorption kinetics on small and full scale zeolite coated adsorbers; A comparison, Applied Thermal Engineering, 50(2) (2013) 1645-1651.

[20] K.H. H.S. Kil, K. Ideta, J. Miyawaki, I. Mochida, S.H. Yoon, Influence of surface functionality on ethanol adsorption behavior in activated carbons analyzed by solid-state NMR, in: B.B.S.e. al. (Ed.) Proceeding of Innovative Materials for Processes in Energy Systems 2013 (IMPRES2013), Fukuoka, Japan, 2013, pp. 525-528.

[21] I.I. El-Sharkawy, B.B. Saha, S. Koyama, J. He, K.C. Ng, C. Yap, Experimental investigation on activated carbon-ethanol pair for solar powered adsorption cooling applications, International Journal of Refrigeration, 31(8) (2008) 1407-1413.

[22] D.M. Ruthven, Principles of Adsorption and Adsorption Processes, Wiley, New York, 1984.

[23] J. Crank, Mathematics of Diffusion, Oxford University Press, London, 1956.

[24] D.M. Ruthven, Diffusion of oxygen and nitrogen in carbon molecular sieve, Chemical Engineering Science, 47(17-18) (1992) 4305-4308.

[25] S.W. Rutherford, J.E. Coons, Adsorption dynamics of carbon dioxide in molecular sieving carbon, Carbon, 41(3) (2003) 405-411.

[26] S.W. Rutherford, J.E. Coons, Equilibrium and kinetics of water adsorption in carbon molecular sieve: Theory and experiment, Langmuir, 20(20) (2004) 8681-8687. 


\section{$\underline{\text { List of Figures }}$}

Fig. 1(a). A pictorial view of laser diffraction particle size analyzer.

Fig. 1(b). Particle size distribution for a sample of parent Maxsorb III.

Fig. 1(c). Particle size distribution for a sample of $\mathrm{KOH}-\mathrm{H}_{2}$ treated Maxsorb III.

Fig. 1(d). Particle size distribution for a sample of $\mathrm{H}_{2}$ treated Maxsorb III.

Fig. 2. Schematic diagram of experimental apparatus.

Fig. 3(a). Adsorption equilibrium of parent Maxsorb III/ethanol pair.

Fig. 3(b). Adsorption equilibrium of $\mathrm{KOH}-\mathrm{H}_{2}$ treated Maxsorb III/ethanol pair.

Fig. 3(c). Adsorption equilibrium of $\mathrm{H}_{2}$-treated Maxsorb III/ethanol pair.

Fig. 4(a). Temporal histories of adsorption uptake and pressure of Maxsorb III/ethanol pair at adsorption temperature $30^{\circ} \mathrm{C}$.

Fig. 4(b). Temporal histories of adsorption uptake and pressure of Maxsorb III/ethanol pair at adsorption temperature $70^{\circ} \mathrm{C}$.

Fig. 5. Temporal histories of adsorption uptake and pressure of $\mathrm{KOH}-\mathrm{H}_{2}$-treated Maxsorb III/ethanol pair at adsorption temperature $30^{\circ} \mathrm{C}$.

Fig. 6. Temporal histories of adsorption uptake and pressure of $\mathrm{H}_{2}$-treated Maxsorb III/ethanol pair at adsorption temperature $30^{\circ} \mathrm{C}$.

Fig. 7(a). Plot of $\ln (1-F)$ versus adsorption time for Maxsorb III/ ethanol pair at $30^{\circ} \mathrm{C}$ adsorption temperature and evaporator pressure of $3.34 \mathrm{kPa}$.

Fig. 7(b). Plot of $\ln (1-F)$ versus adsorption time for Maxsorb III/ ethanol pair at $70^{\circ} \mathrm{C}$ adsorption temperature and evaporator pressure of $11.26 \mathrm{kPa}$.

Fig. 8. Plot of $\ln (1-F)$ versus adsorption time for $\mathrm{KOH}-\mathrm{H}_{2}$-treated Maxsorb III/ethanol pair at $30^{\circ} \mathrm{C}$ adsorption temperature and evaporator pressure of $2.27 \mathrm{kPa}$.

Fig. 9. Plot of $\ln (1-F)$ versus adsorption time for $\mathrm{H}_{2}$-treated Maxsorb III/ethanol pair at $30^{\circ} \mathrm{C}$ adsorption temperature and evaporator pressure of $3.36 \mathrm{kPa}$.

Fig. 10(a). Fractional uptake verses time for Maxsorb III/ethanol pair at adsorption temperature $30^{\circ} \mathrm{C}, 50^{\circ} \mathrm{C}$ and $70^{\circ} \mathrm{C}$ (symbols present experiments and lines present FD model). 
Fig. 10(b). Fractional uptake verses time for $\mathrm{KOH}-\mathrm{H}_{2}$ treated Maxsorb III/ethanol pair at adsorption temperature $30^{\circ} \mathrm{C}, 50^{\circ} \mathrm{C}$ and $70^{\circ} \mathrm{C}$ (symbols present experiments and lines present FD model).

Fig. 10(c). Fractional uptake verses time for $\mathrm{H}_{2}$-treated Maxsorb III/ethanol pair at adsorption temperature $30^{\circ} \mathrm{C}, 50^{\circ} \mathrm{C}$ and $70^{\circ} \mathrm{C}$ (symbols present experiments and lines present $\mathrm{FD}$ model). Fig. 11. Plot of diffusion time constant versus equilibrium pressure for assorted pairs at $50{ }^{\circ} \mathrm{C}$. Fig. 12. Arrhenius plot of the assorted pairs. 


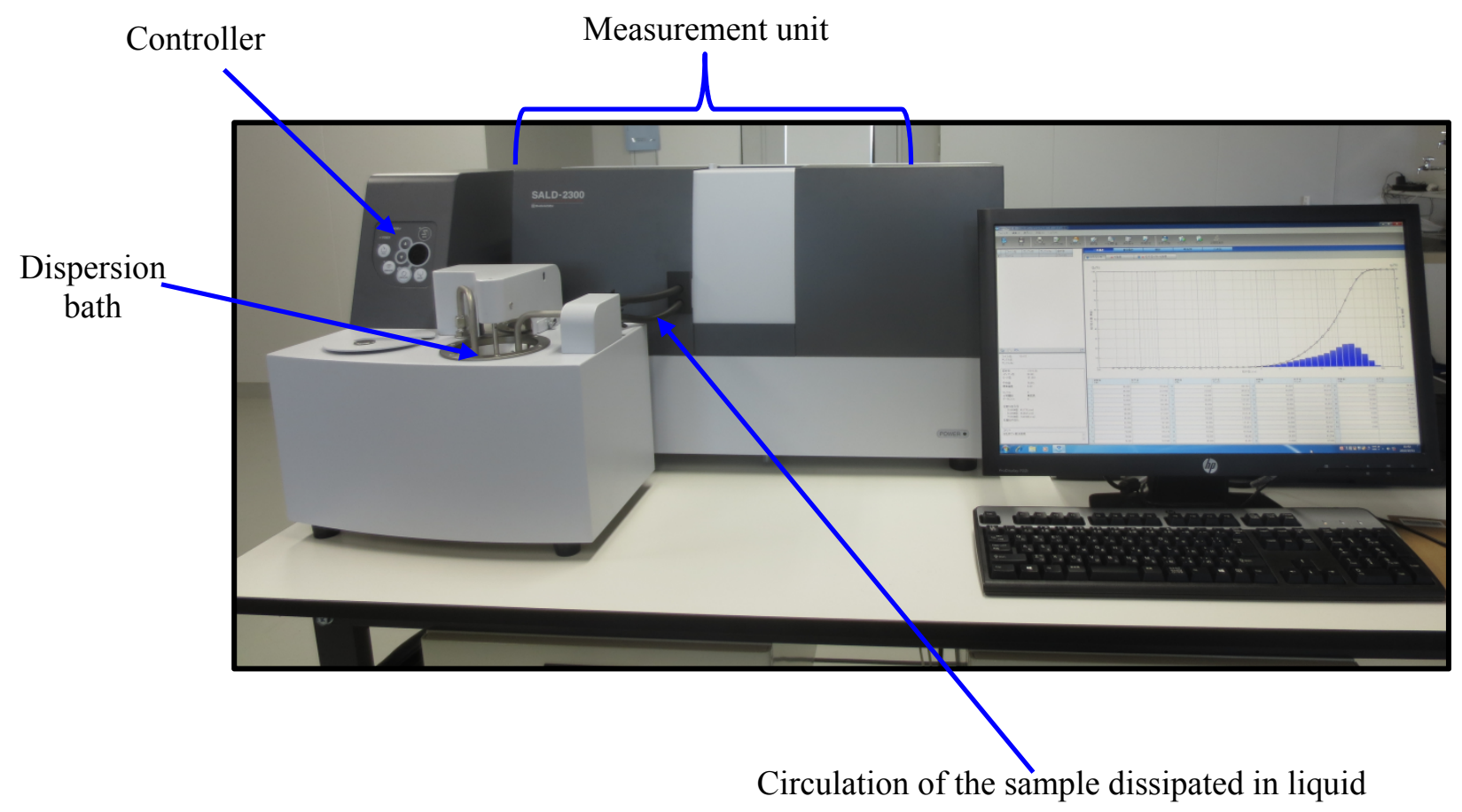

Fig. 1(a). A pictorial view of laser diffraction particle size analyzer. 


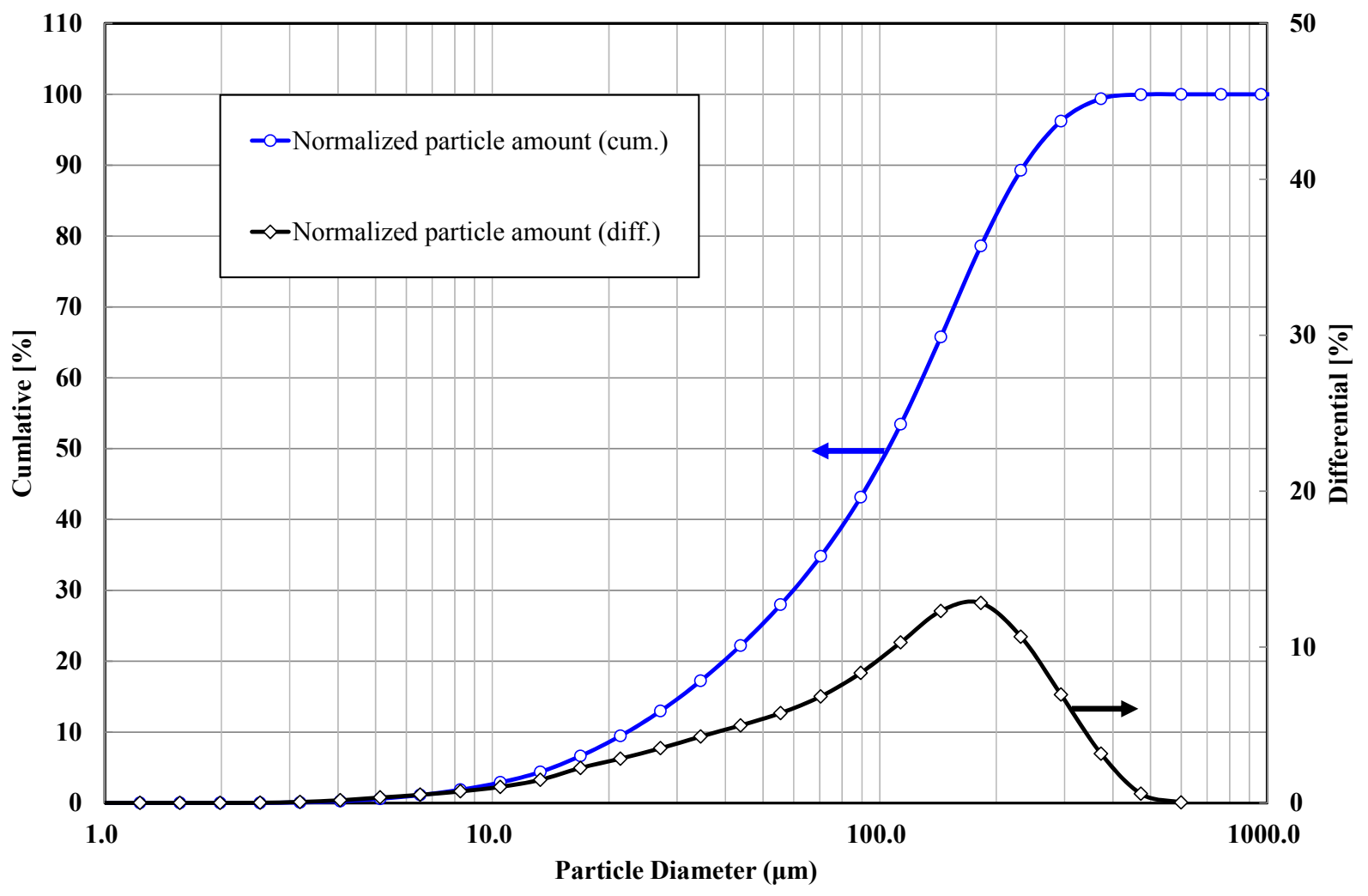

Fig. 1(b). Particle size distribution for a sample of parent Maxsorb III. 


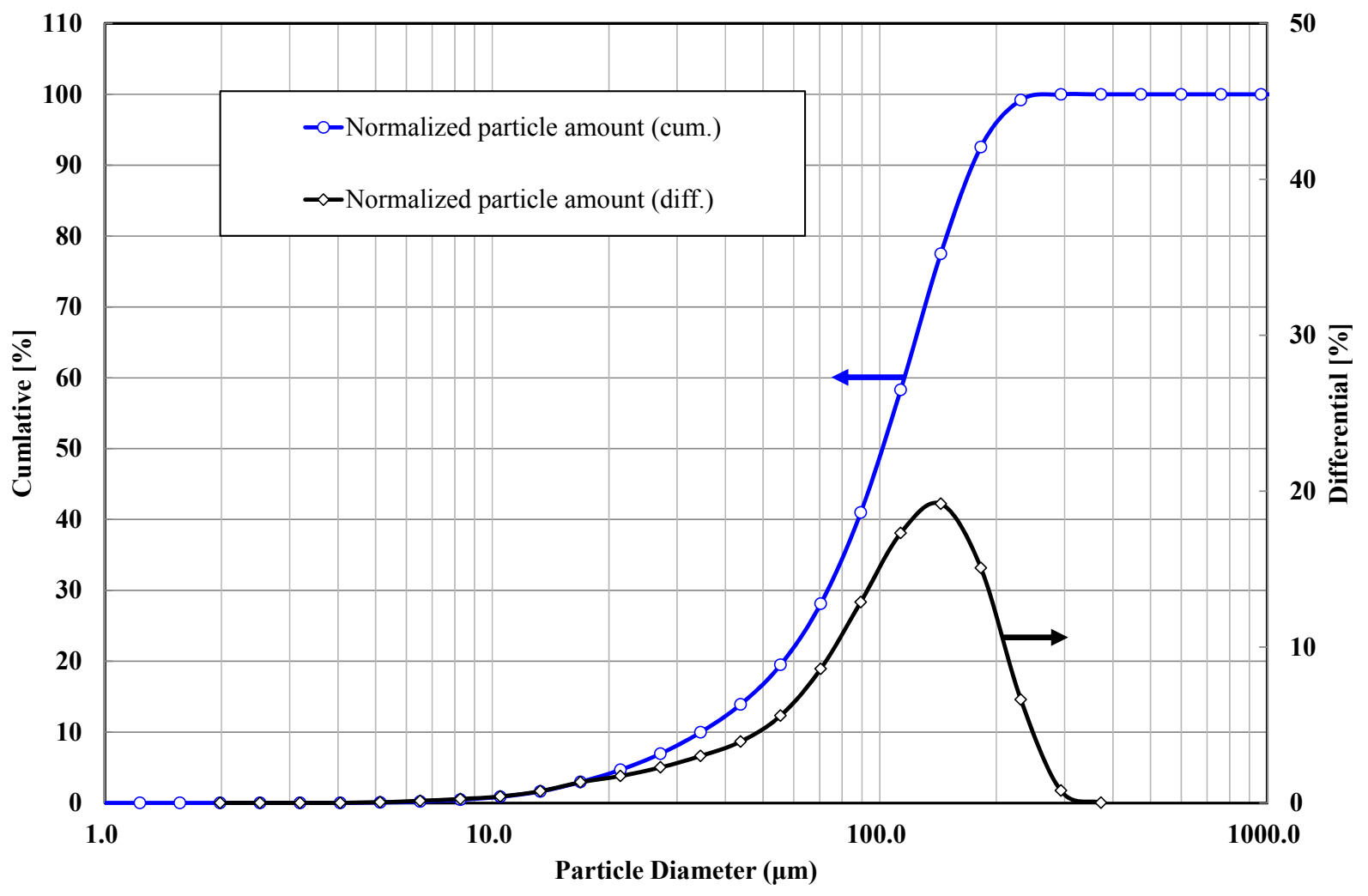

Fig. 1(c). Particle size distribution for a sample of $\mathrm{KOH}-\mathrm{H}_{2}$ treated Maxsorb III. 


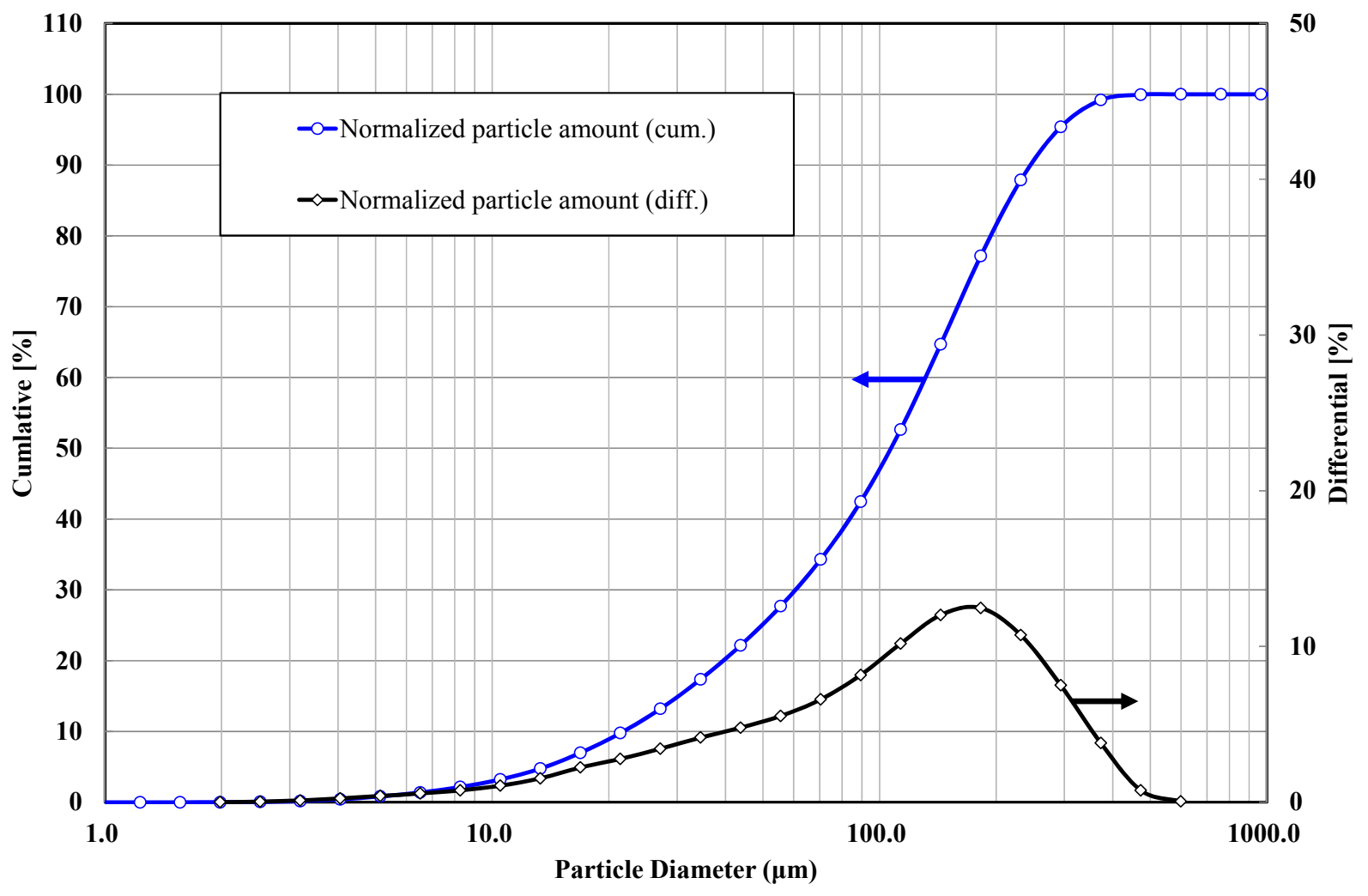

Fig. 1(d). Particle size distribution for a sample of $\mathrm{H}_{2}$ treated Maxsorb III. 


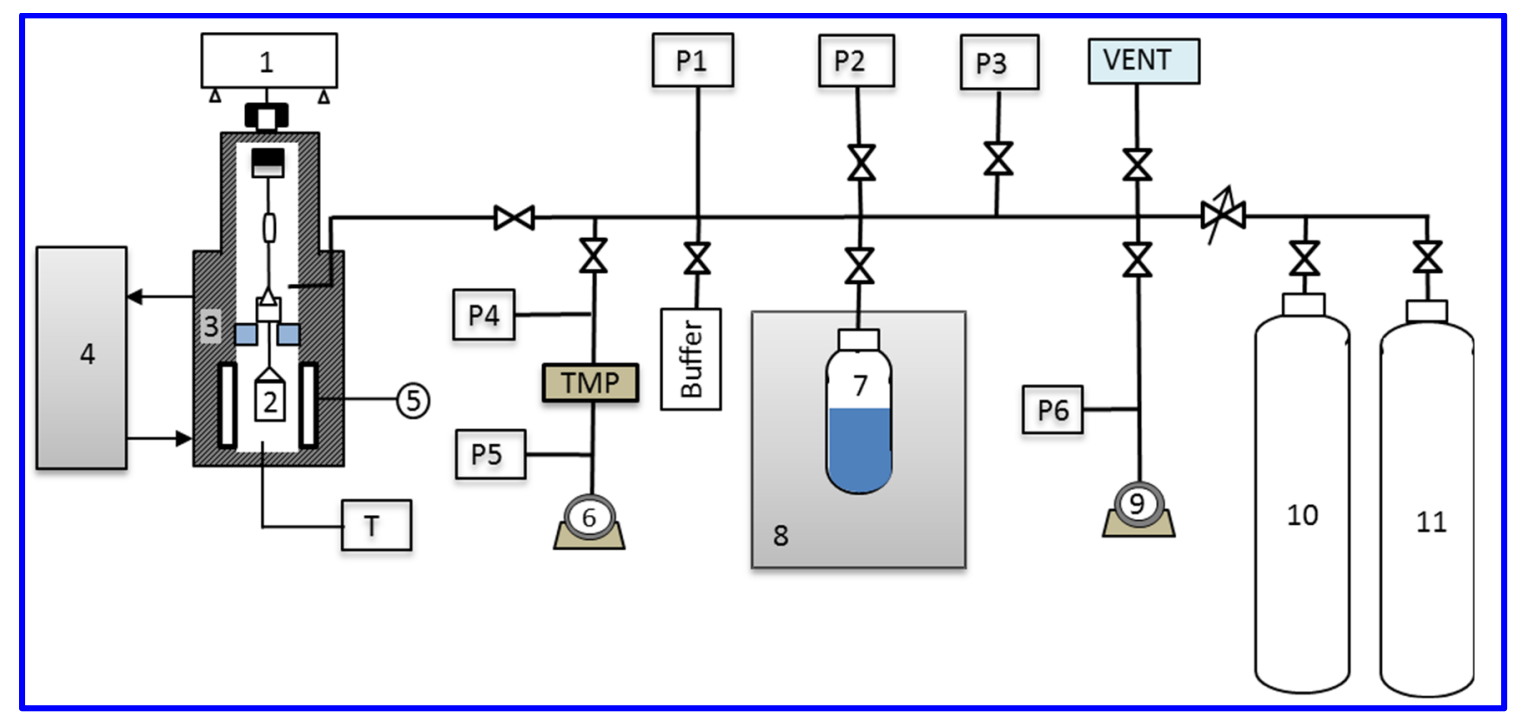

1. Magnetic suspension balance unit; 2. Sample basket; 3. Circulation oil jacket; 4. Oil bath ; 5. Sheathed heater; 6. Rotary pump; 7. Liquid ethanol; 8. Isothermal oil bath; 9. Diaphragm pump; 10. Nitrogen cylinder; 11. Helium cylinder; T:Thermocouple; P1-P6:Pressure gauges; TMP:Turbomolecular pump.

Fig. 2. Schematic diagram of experimental apparatus. 


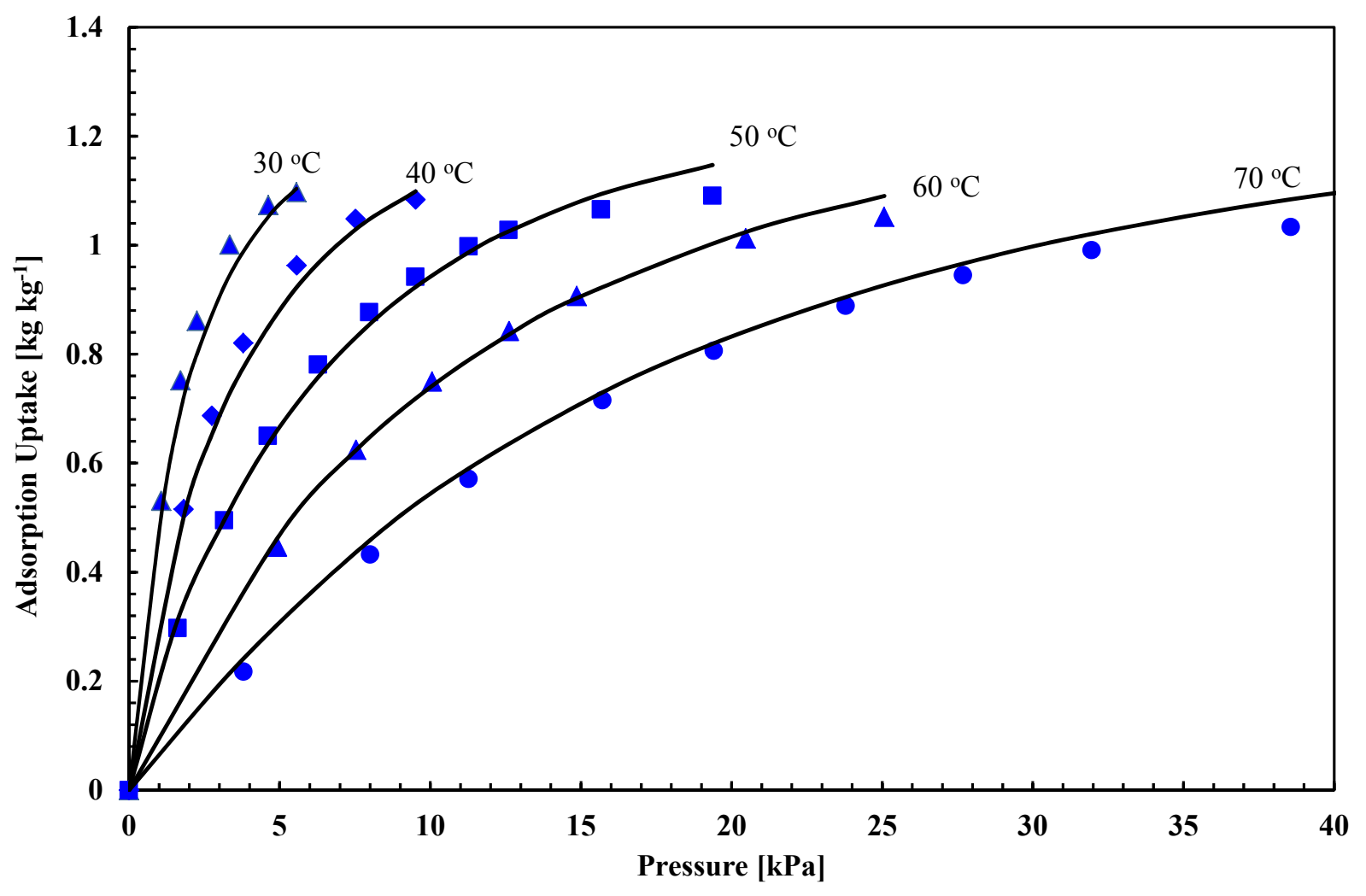

Fig. 3(a). Adsorption equilibrium of parent Maxsorb III/ethanol pair. 


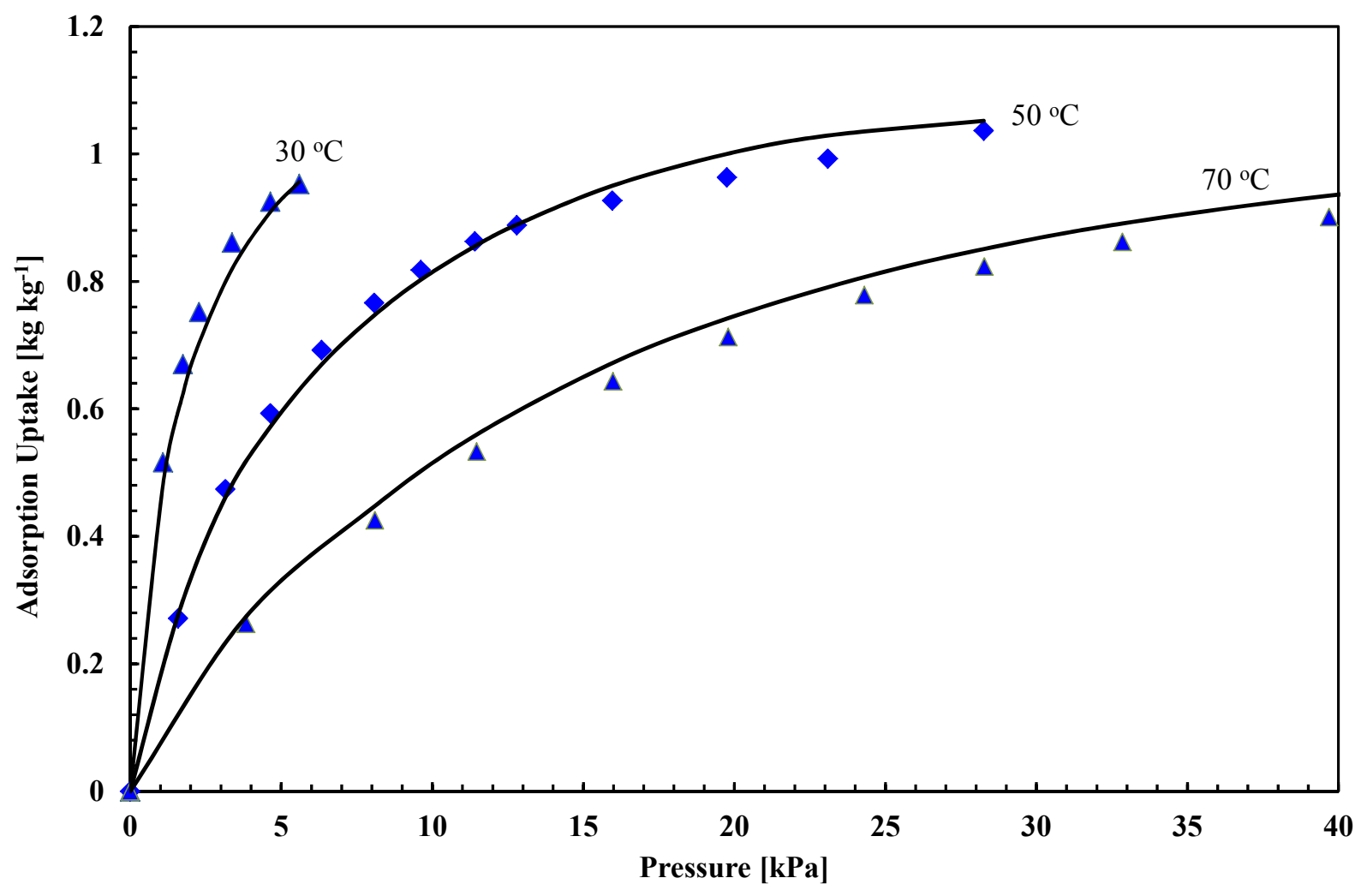

Fig. 3(b). Adsorption equilibrium of $\mathrm{KOH}-\mathrm{H}_{2}$ treated Maxsorb III/ethanol pair. 


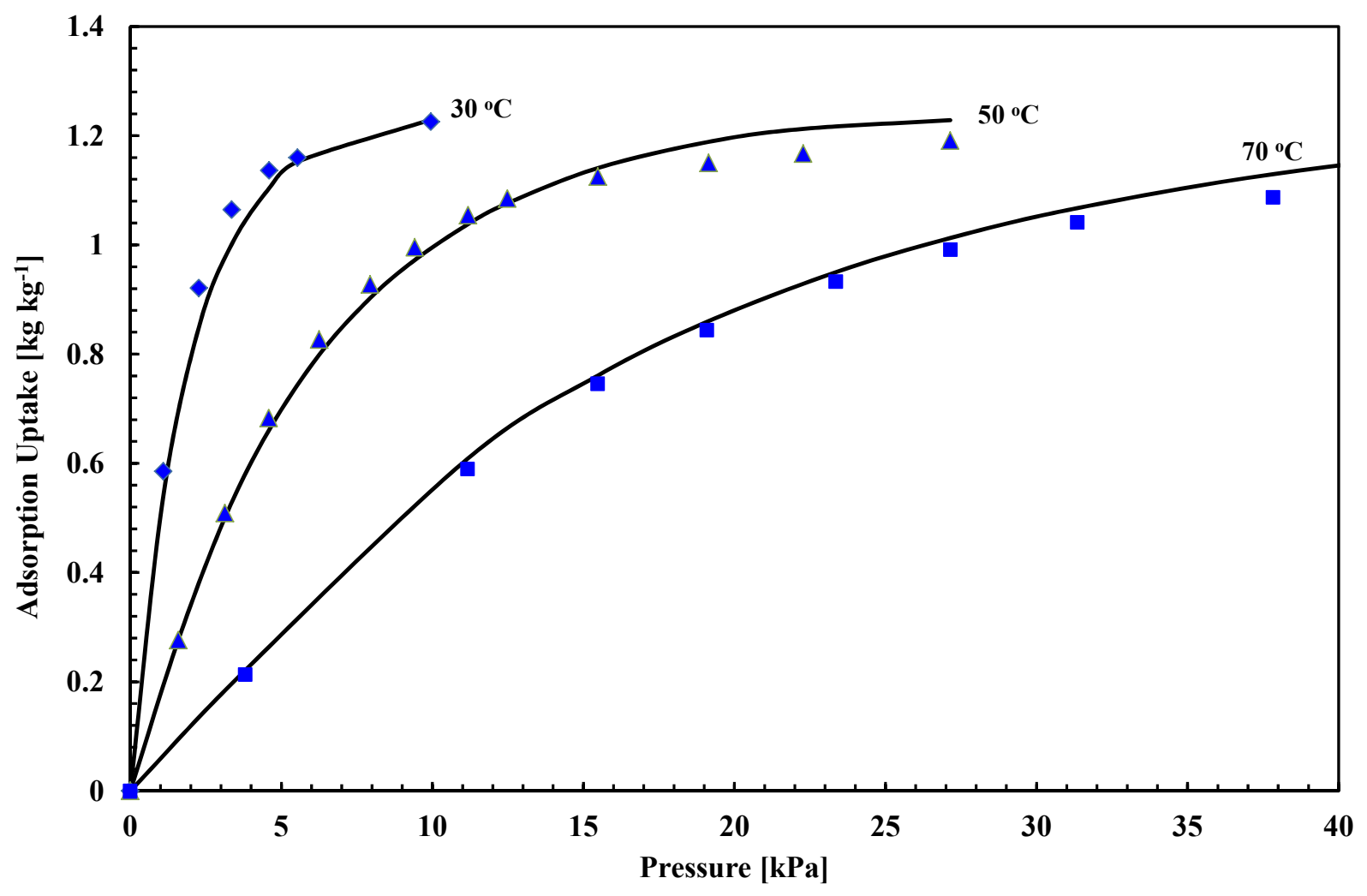

Fig. 3(c). Adsorption equilibrium of $\mathrm{H}_{2}$-treated Maxsorb III/ethanol pair. 


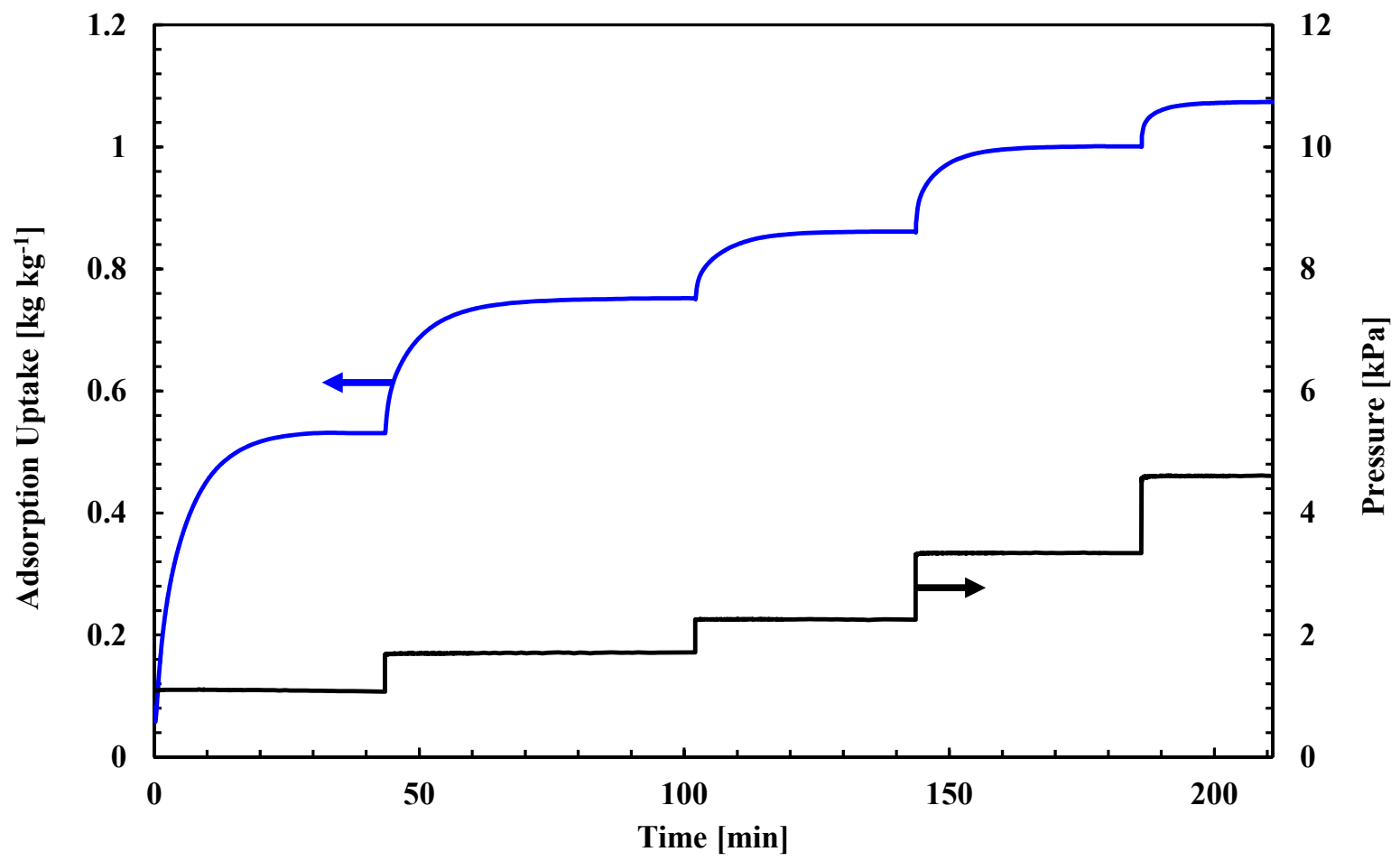

Fig. 4(a). Temporal histories of adsorption uptake and pressure of Maxsorb III/ethanol pair at adsorption temperature $30^{\circ} \mathrm{C}$. 


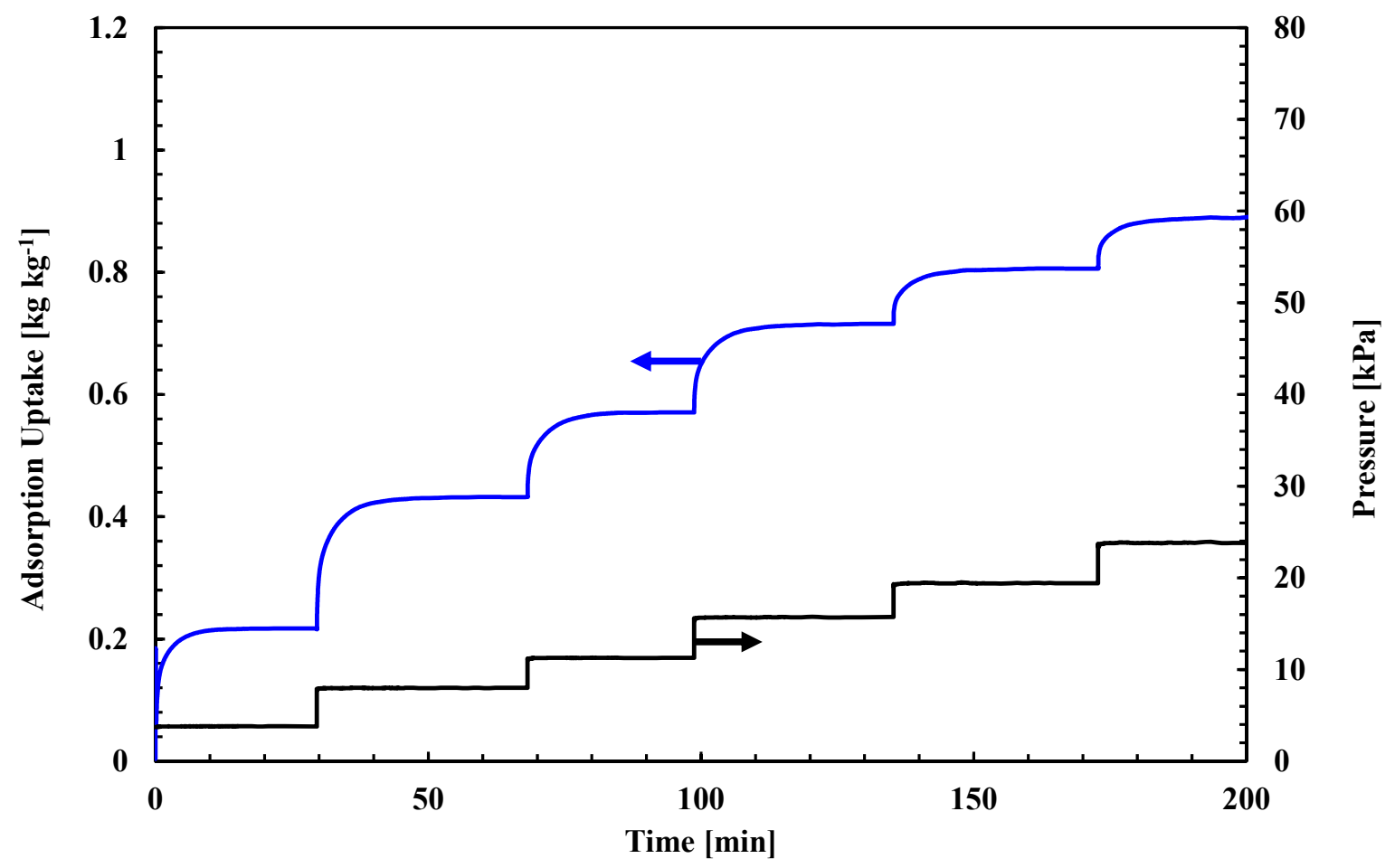

Fig. 4(b). Temporal histories of adsorption uptake and pressure of Maxsorb III/ethanol pair at adsorption temperature $70{ }^{\circ} \mathrm{C}$. 


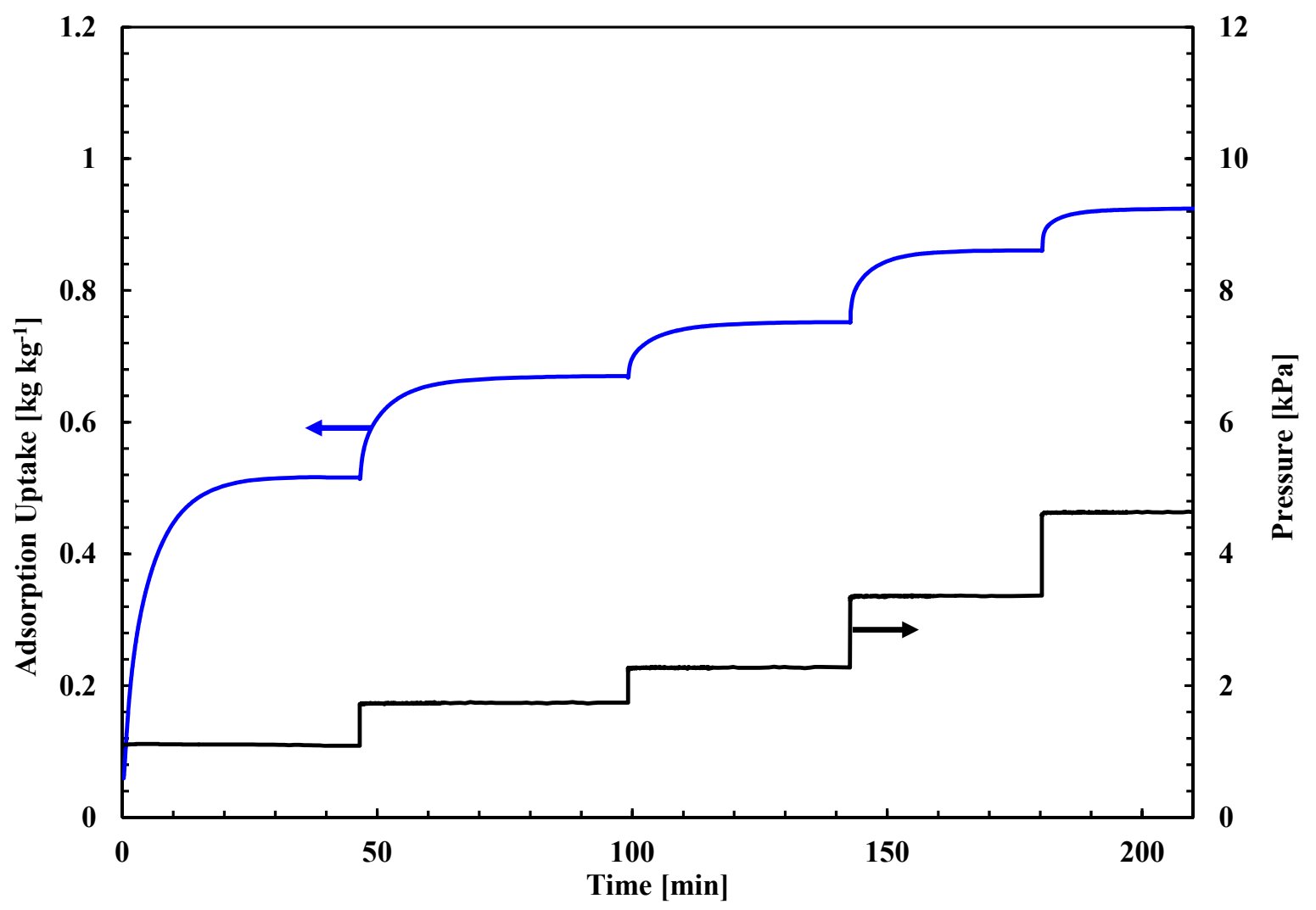

Fig. 5. Temporal histories of adsorption uptake and pressure of $\mathrm{KOH}-\mathrm{H}_{2}$-treated Maxsorb $\mathrm{III} /$ ethanol pair at adsorption temperature $30^{\circ} \mathrm{C}$. 


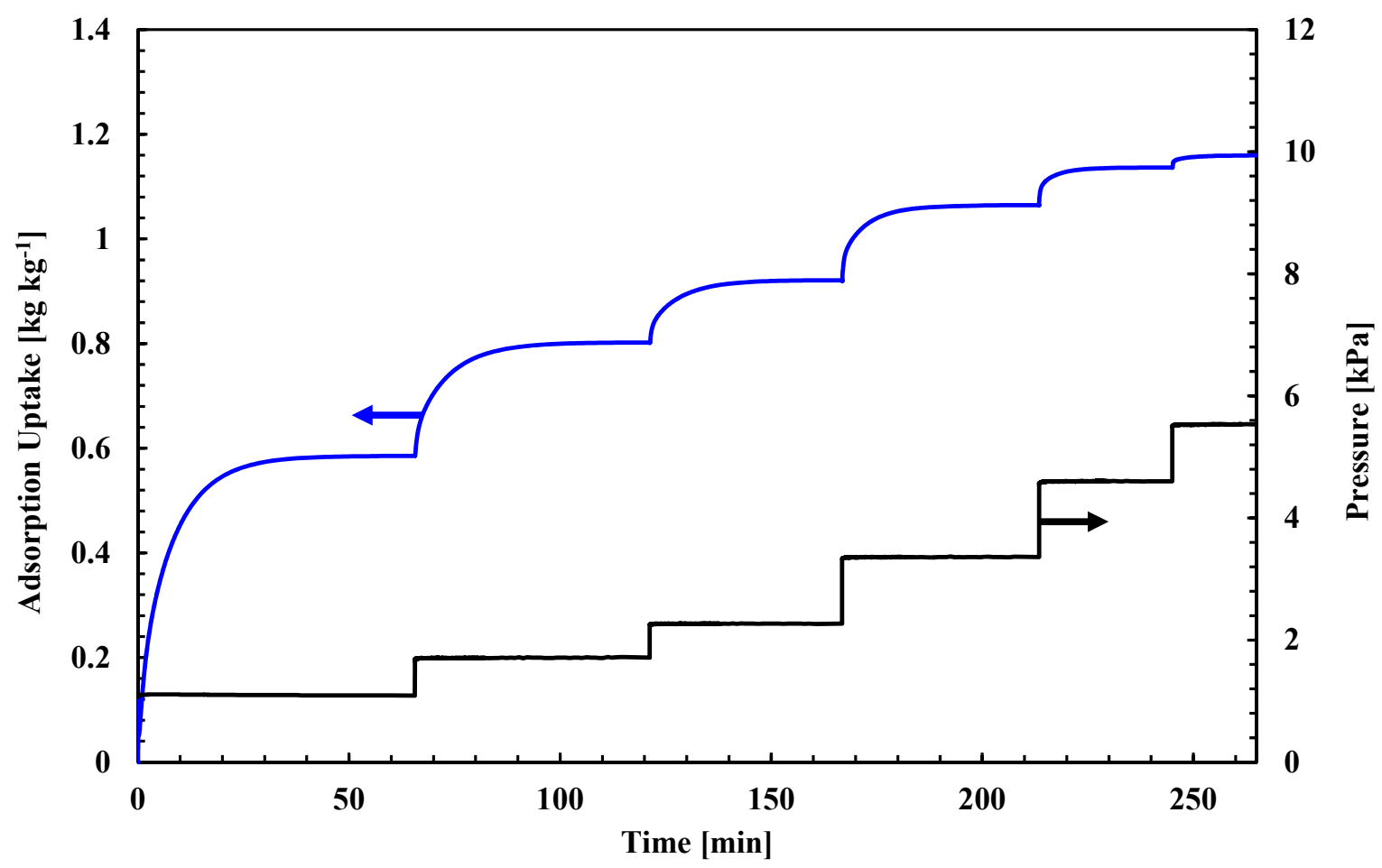

Fig. 6. Temporal histories of adsorption uptake and pressure of $\mathrm{H}_{2}$-treated Maxsorb III/ethanol pair at adsorption temperature $30^{\circ} \mathrm{C}$. 


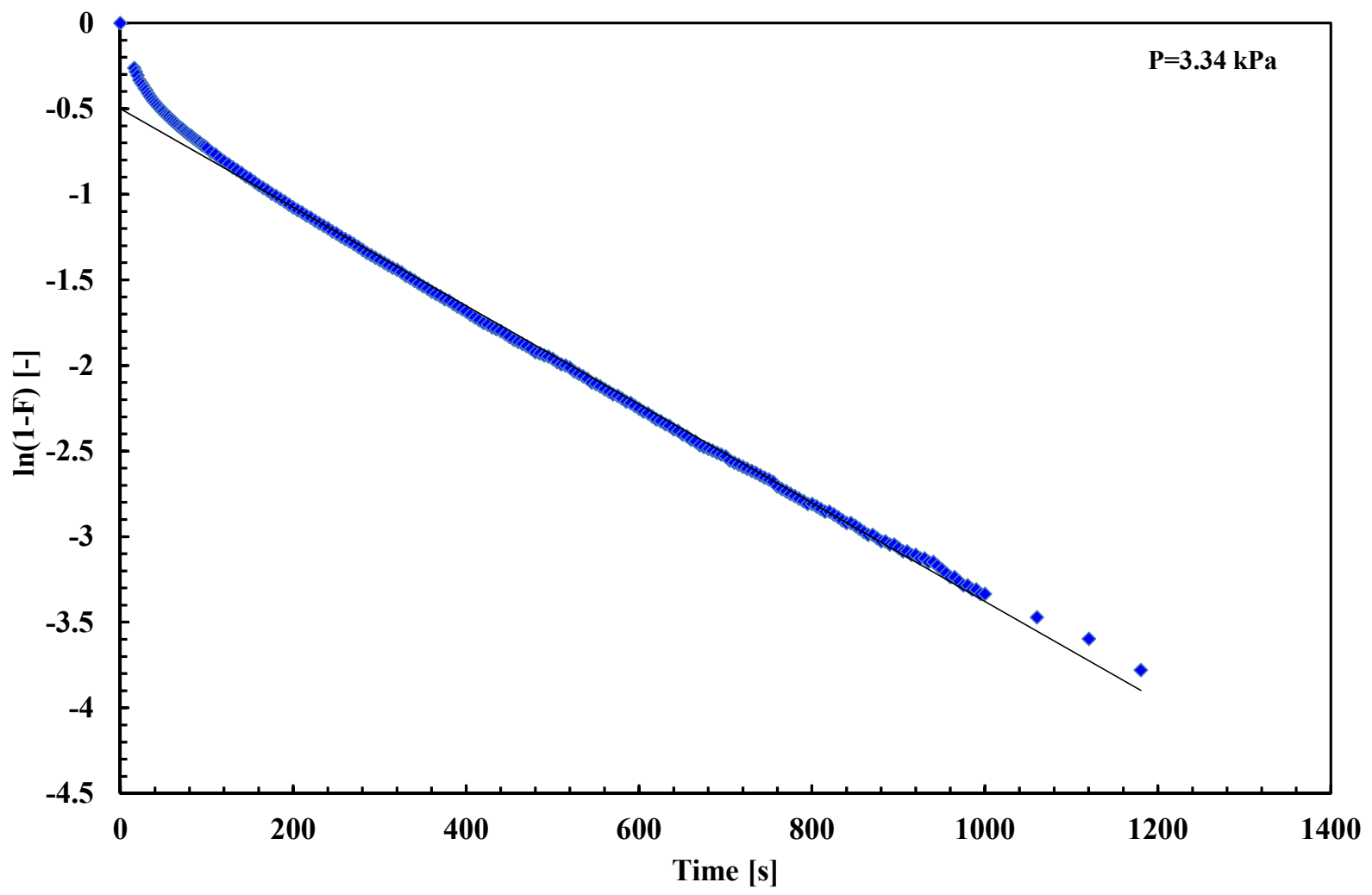

Fig. 7(a). Plot of $\ln (1-F)$ versus adsorption time for Maxsorb III/ ethanol pair at $30^{\circ} \mathrm{C}$ adsorption temperature and evaporator pressure of $3.34 \mathrm{kPa}$. 


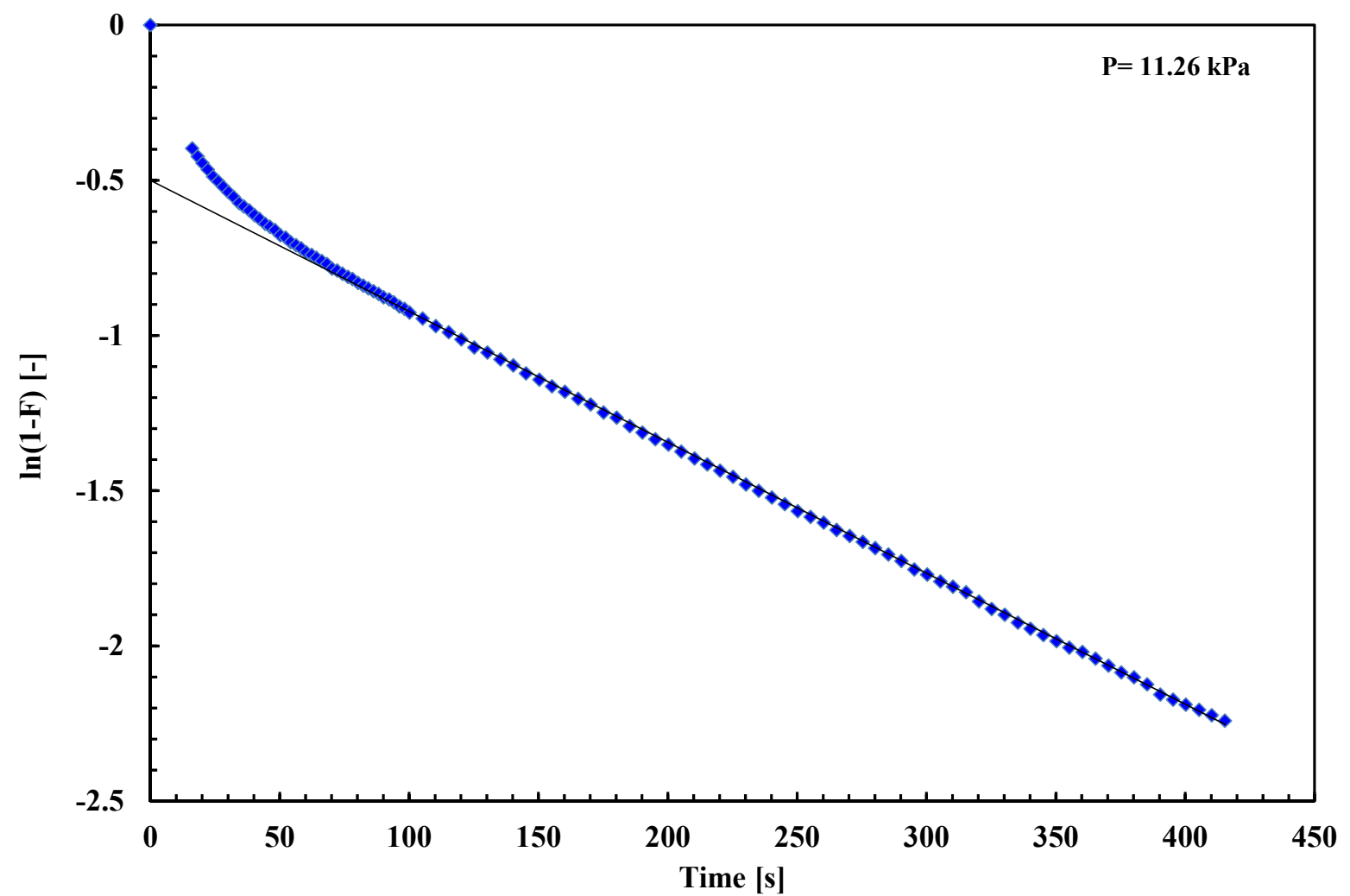

Fig. 7(b). Plot of $\ln (1-F)$ versus adsorption time for Maxsorb III/ ethanol pair at $70^{\circ} \mathrm{C}$ adsorption temperature and evaporator pressure of $11.26 \mathrm{kPa}$. 


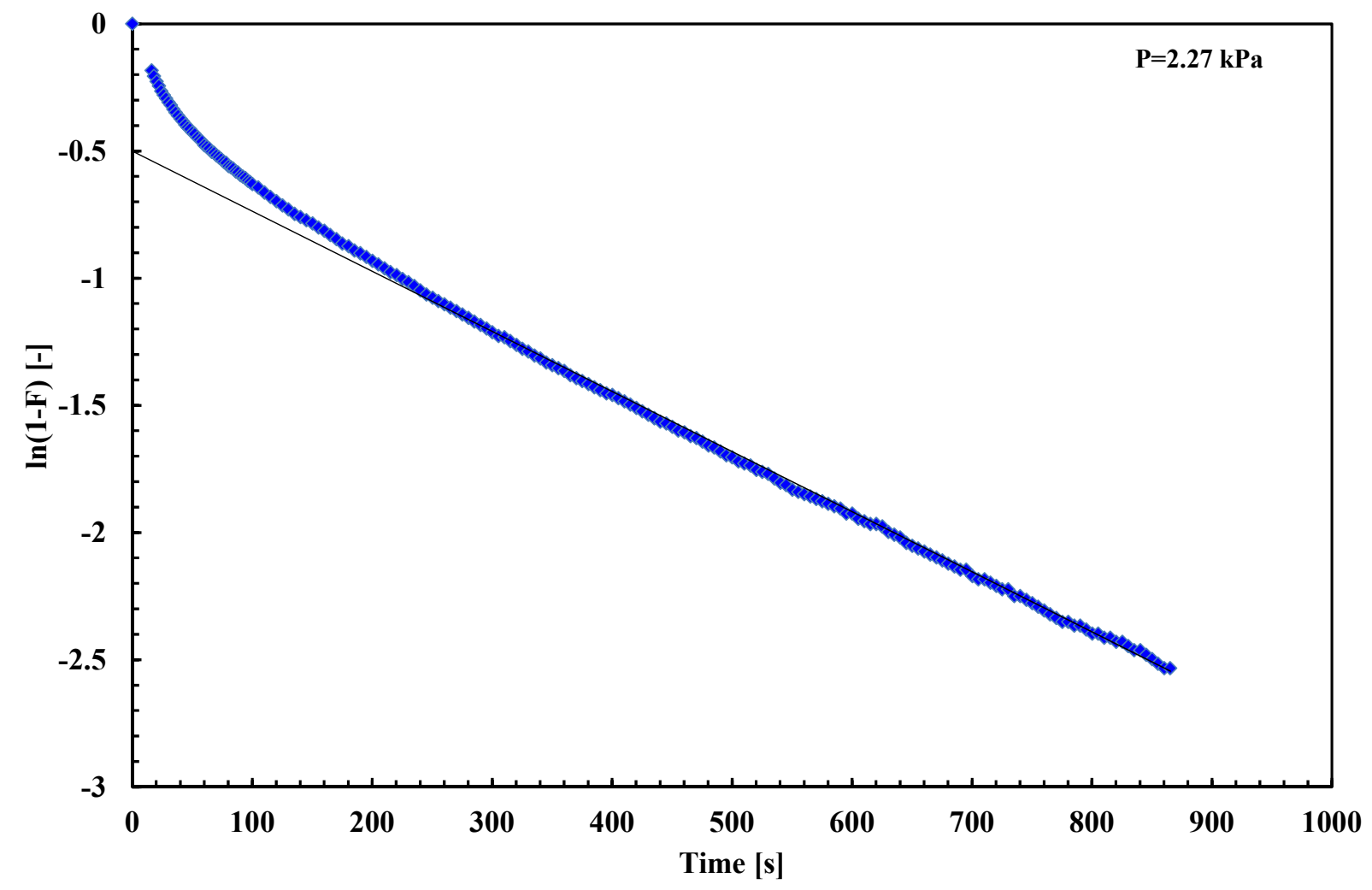

Fig. 8. Plot of $\ln (1-F)$ versus adsorption time for $\mathrm{KOH}-\mathrm{H}_{2}$-treated Maxsorb III/ethanol pair at $30^{\circ} \mathrm{C}$ adsorption temperature and evaporator pressure of $2.27 \mathrm{kPa}$. 


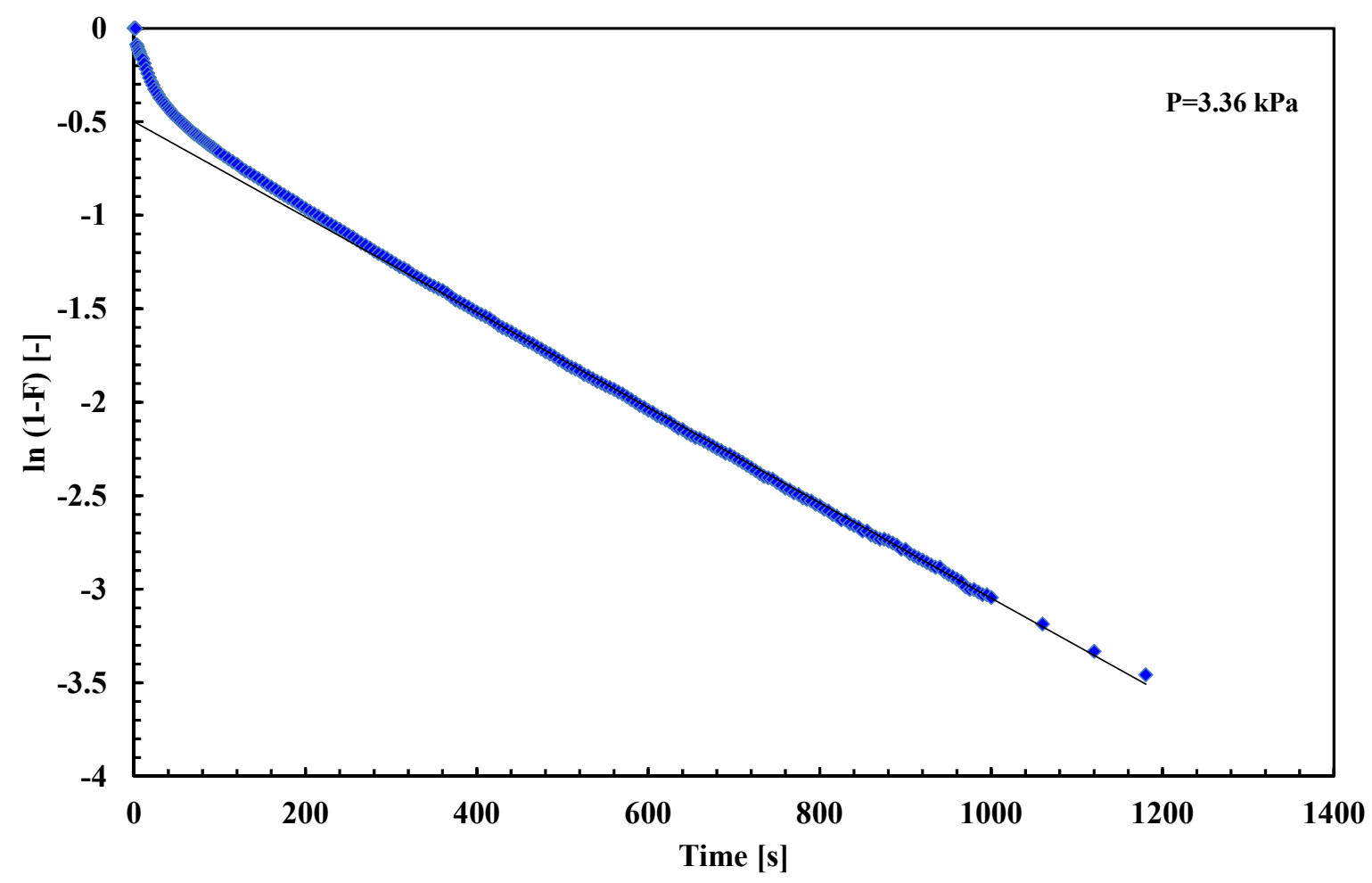

Fig. 9. Plot of $\ln (1-F)$ versus adsorption time for $\mathrm{H}_{2}$-treated Maxsorb III/ethanol pair at $30^{\circ} \mathrm{C}$ adsorption temperature and evaporator pressure of $3.36 \mathrm{kPa}$. 


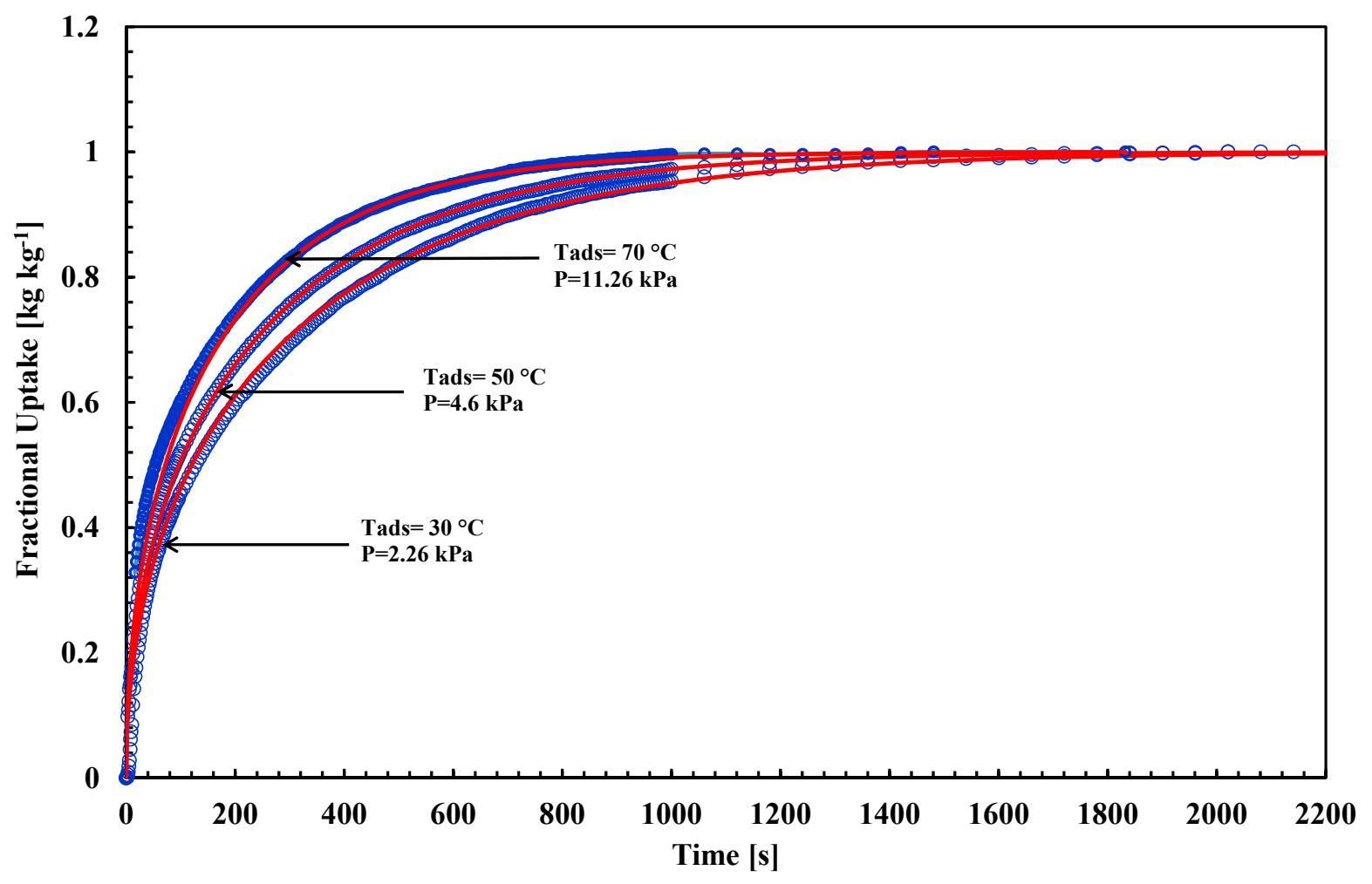

Fig. 10(a). Fractional uptake verses time for Maxsorb III/ethanol pair at adsorption temperature $30^{\circ} \mathrm{C}, 50^{\circ} \mathrm{C}$ and $70^{\circ} \mathrm{C}$ (symbols present experiments and lines present FD model). 


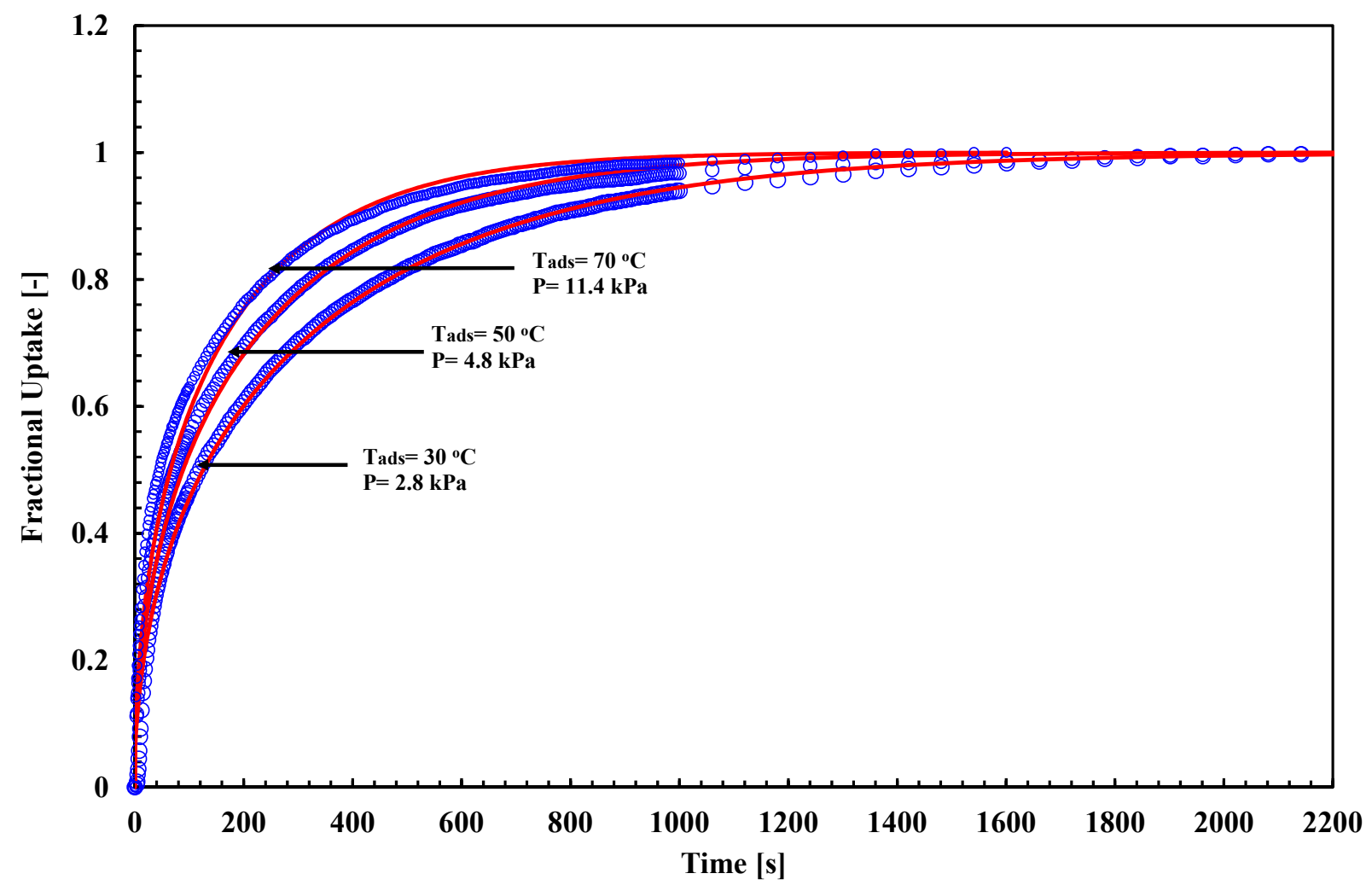

Fig. 10(b). Fractional uptake verses time for $\mathrm{KOH}-\mathrm{H}_{2}$ treated Maxsorb III/ethanol pair at adsorption temperature $30^{\circ} \mathrm{C}, 50^{\circ} \mathrm{C}$ and $70^{\circ} \mathrm{C}$ (symbols present experiments and lines present $\mathrm{FD}$ model). 


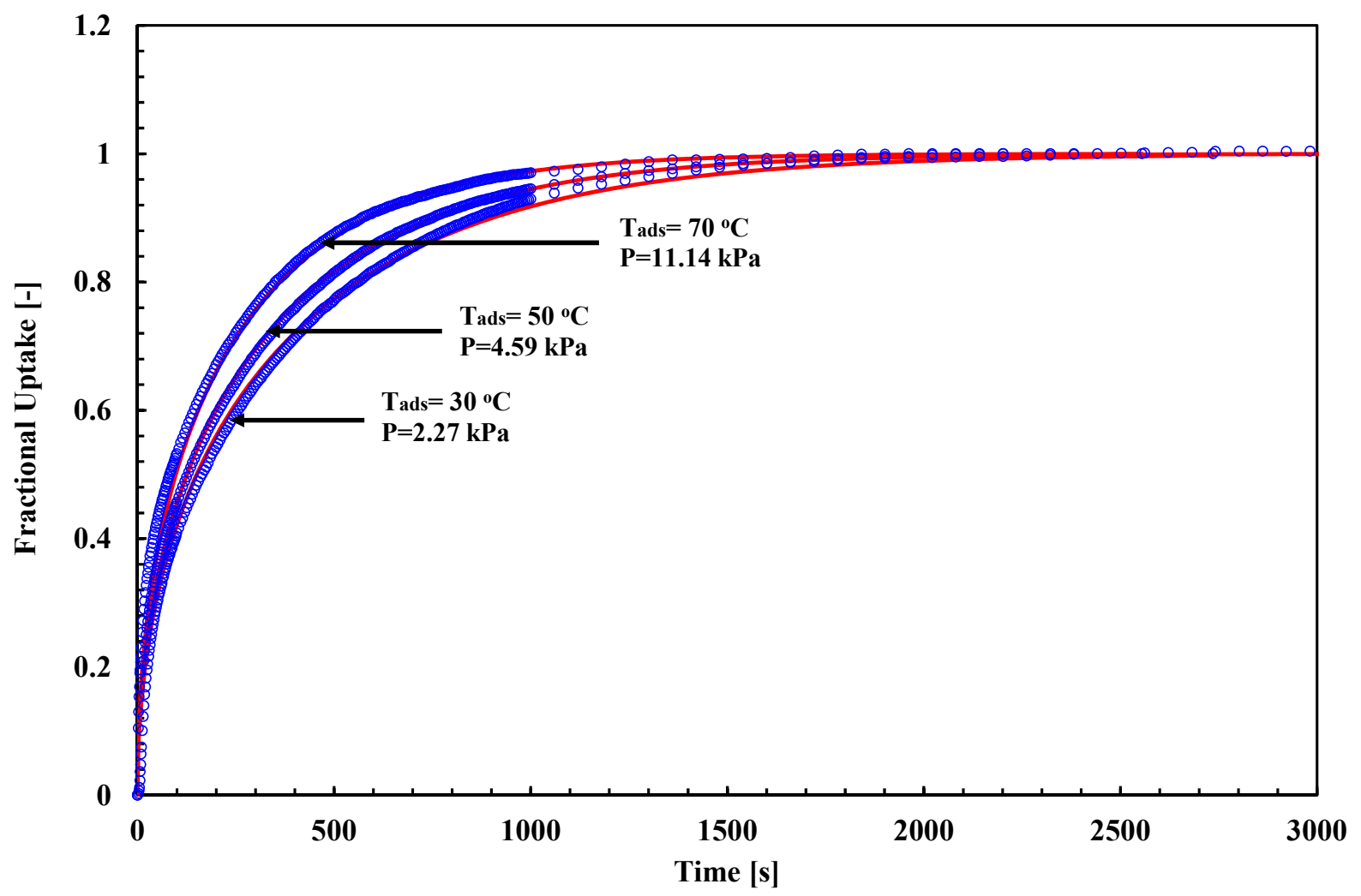

Fig. 10(c). Fractional uptake verses time for $\mathrm{H}_{2}$-treated Maxsorb III/ethanol pair at adsorption temperature $30^{\circ} \mathrm{C}, 50^{\circ} \mathrm{C}$ and $70^{\circ} \mathrm{C}$ (symbols present experiments and lines present FD model). 


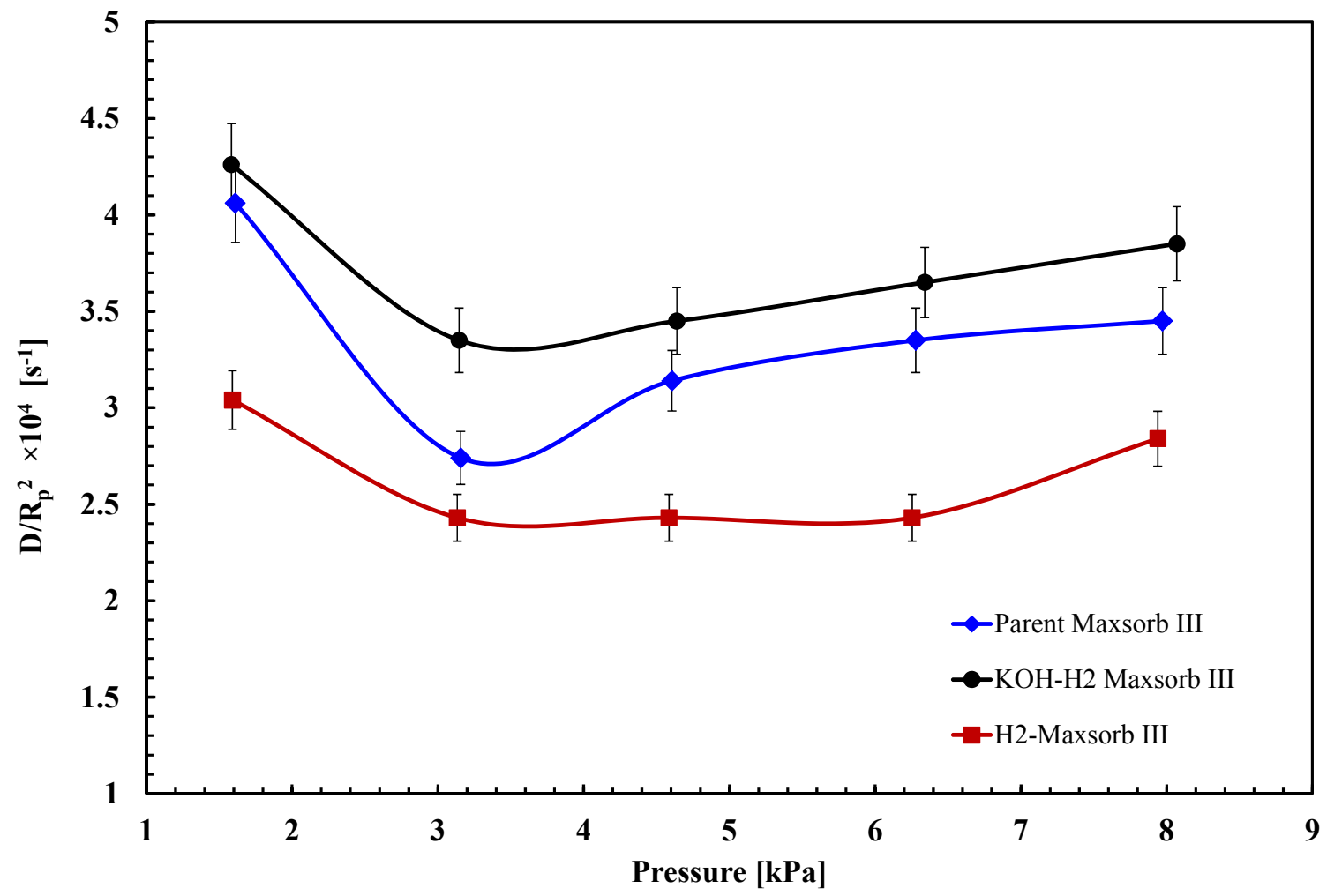

Fig. 11. Plot of diffusion time constant versus equilibrium pressure for assorted pairs at $50{ }^{\circ} \mathrm{C}$ (error bars present 5\%). 


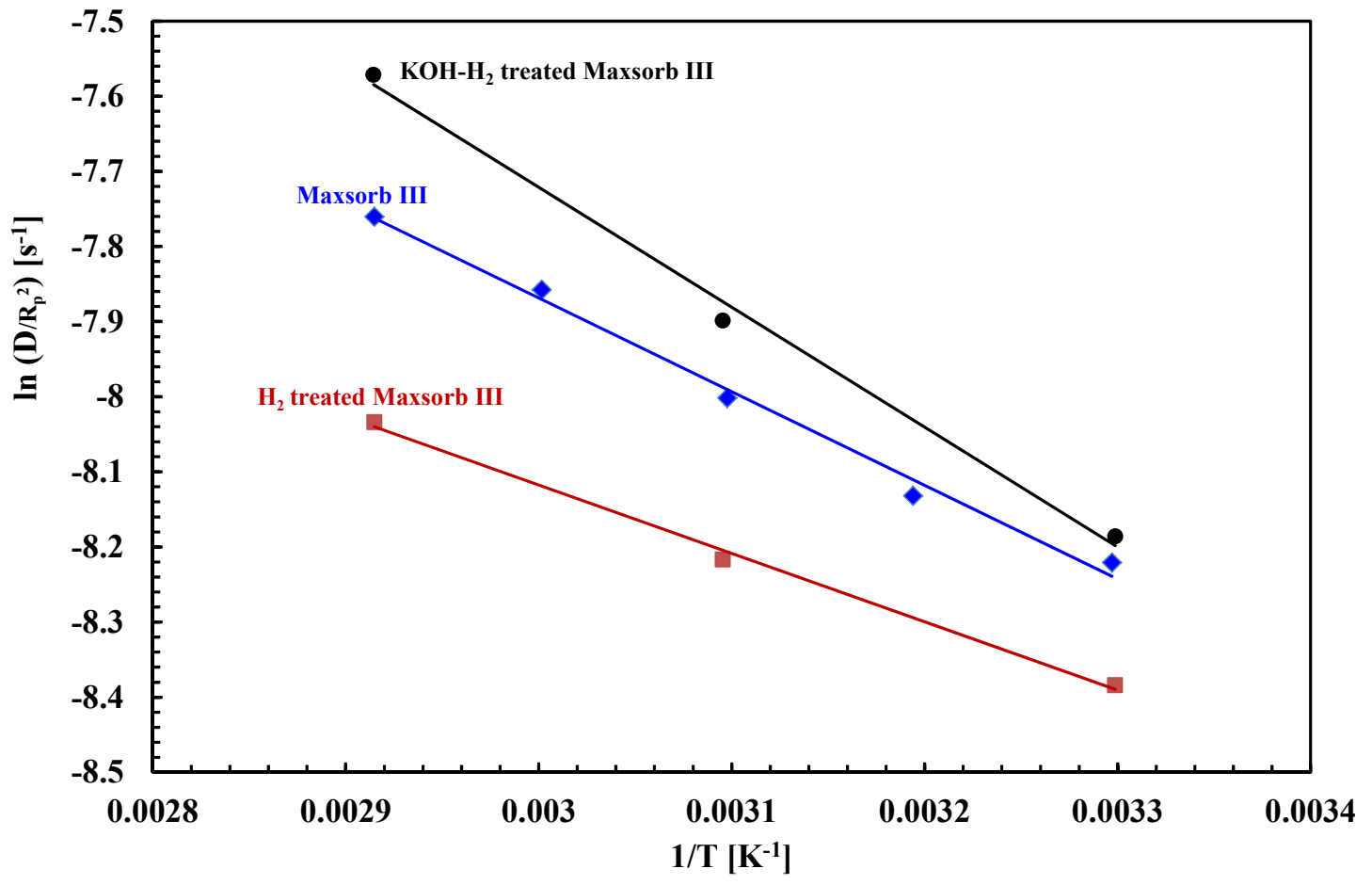

Fig. 12. Arrhenius plot of the assorted pairs. 


\section{$\underline{\text { List of Tables }}$}

Table 1 Thermo-physical properties of parent and surface treated Maxsorb III [20].

Table 2 Elemental composition of parent, $\mathrm{KOH}-\mathrm{H}_{2}$ and $\mathrm{H}_{2}$ treated Maxsorb III [20].

Table 3 Isotherm parameters of assorted adsorbent/refrigerant pairs.

Table 4 Kinetic measurements of parent Maxsorb III/ethanol pair.

Table 5 Kinetic measurements of $\mathrm{KOH}-\mathrm{H}_{2}$ treated Maxsorb III/ethanol pair

Table 6 Kinetic measurements of $\mathrm{H}_{2}$-treated Maxsorb III/ethanol pair.

Table 7 Parameters of Arrhenius equation of studied adsorbent/refrigerant pairs. 


\section{Table 1}

Thermo-physical properties of parent and surface treated Maxsorb III [20].

\begin{tabular}{lccc}
\hline Sample & $\begin{array}{c}\text { Total surface area } \\
{\left[\mathbf{m}^{\mathbf{2}} \mathbf{g}^{-\mathbf{1}}\right]}\end{array}$ & $\begin{array}{c}\text { Micropore volume } \\
{\left[\mathbf{c m}^{\mathbf{3}} \mathbf{g}^{-\mathbf{1}}\right]}\end{array}$ & $\begin{array}{c}\text { Average pore width } \\
{[\mathbf{n m}]}\end{array}$ \\
\hline Parent Maxsorb III & 3045 & 1.70 & 1.11 \\
KOH-H2-Maxsorb III & 2992 & 1.65 & 1.11 \\
H2-Maxsorb III $^{\text {KO }}$ & 3029 & 1.73 & 1.15 \\
\hline
\end{tabular}




\section{Table 2}

Elemental composition of parent, $\mathrm{KOH}-\mathrm{H}_{2}$ and $\mathrm{H}_{2}$ treated Maxsorb III [20].

\begin{tabular}{|c|c|c|c|c|c|c|}
\hline Sample & $\begin{array}{c}\mathrm{C} \\
{[\%]}\end{array}$ & $\begin{array}{c}\mathbf{H} \\
{[\%]}\end{array}$ & $\begin{array}{c}\mathrm{N} \\
{[\%]}\end{array}$ & $\begin{array}{c}\text { O(diff.) } \\
{[\%]}\end{array}$ & $\mathrm{O} / \mathrm{C}$ & $\begin{array}{l}\text { Ash } \\
{[\%]}\end{array}$ \\
\hline Parent Maxsorb III & 95.13 & 0.14 & 0.25 & 4.35 & 0.034 & 0.13 \\
\hline KOH-H & 89.15 & 0.27 & 0.08 & 10.46 & 0.088 & - \\
\hline $\mathrm{H}_{2}$-Maxsorb III & 97.91 & 0.22 & 0.12 & 1.75 & 0.013 & - \\
\hline
\end{tabular}




\section{Table 3}

Isotherm parameters of assorted adsorbent/refrigerant pairs.

\begin{tabular}{lccc}
\hline Adsorbent/refrigerant pair & $\begin{array}{c}\mathbf{W}_{\mathbf{0}} \\
{\left[\mathbf{k g ~ k g}^{-1}\right]}\end{array}$ & $\begin{array}{c}\mathbf{n} \\
{[-]}\end{array}$ & $\begin{array}{c}\mathbf{E} \\
{\left[\mathbf{k J ~ k g}^{-1}\right]}\end{array}$ \\
\hline Parent Maxsorb III/ethanol & 1.2 & 1.8 & 139.5 \\
$\mathrm{KOH}-\mathrm{H}_{2}$ treated Maxsorb III/ethanol & 1.0 & 1.9 & 152 \\
$\mathrm{H}_{2}$ treated Maxsorb III/ethanol & & & 144 \\
\hline
\end{tabular}




\section{Table 4}

Kinetic measurements of parent Maxsorb III/ethanol pair.

\begin{tabular}{|c|c|c|}
\hline $\begin{array}{l}\text { Tads, } \\
{\left[{ }^{\circ} \mathrm{C}\right]}\end{array}$ & $\begin{array}{c}\text { Equilibrium Pressure, } \\
\qquad[\mathrm{kPa}]\end{array}$ & $\begin{array}{c}\mathrm{D} / \mathrm{R}_{\mathrm{p}}^{2} \\
{\left[\mathrm{~s}^{-1}\right]}\end{array}$ \\
\hline \multirow[t]{2}{*}{30.2} & 2.3 & $2.54 \times 10^{-4}$ \\
\hline & 3.3 & $2.84 \times 10^{-4}$ \\
\hline \multirow[t]{4}{*}{39.9} & 1.8 & $2.94 \times 10^{-4}$ \\
\hline & 2.8 & $2.43 \times 10^{-4}$ \\
\hline & 3.8 & $2.94 \times 10^{-4}$ \\
\hline & 5.6 & $3.45 \times 10^{-4}$ \\
\hline \multirow[t]{5}{*}{49.7} & 1.6 & $4.06 \times 10^{-4}$ \\
\hline & 3.2 & $2.74 \times 10^{-4}$ \\
\hline & 4.6 & $3.14 \times 10^{-4}$ \\
\hline & 6.3 & $3.35 \times 10^{-4}$ \\
\hline & 8.0 & $3.45 \times 10^{-4}$ \\
\hline \multirow[t]{4}{*}{60.0} & 4.9 & $4.06 \times 10^{-4}$ \\
\hline & 7.5 & $3.55 \times 10^{-4}$ \\
\hline & 10.0 & $3.8 \times 10^{-4}$ \\
\hline & 12.6 & $4.06 \times 10^{-4}$ \\
\hline \multirow[t]{4}{*}{69.9} & 8.0 & $4.67 \times 10^{-4}$ \\
\hline & 11.3 & $4.26 \times 10^{-4}$ \\
\hline & 15.7 & $4.06 \times 10^{-4}$ \\
\hline & 19.4 & $4.06 \times 10^{-4}$ \\
\hline
\end{tabular}




\section{Table 5}

Kinetic measurements of $\mathrm{KOH}-\mathrm{H}_{2}$ treated Maxsorb III/ethanol pair.

\begin{tabular}{ccc}
\hline $\begin{array}{c}\mathrm{T}_{\mathrm{ads}}, \\
{\left[{ }^{\circ} \mathrm{C}\right]}\end{array}$ & $\begin{array}{c}\text { Equilibrium Pressure, } \\
{[\mathrm{kPa}]}\end{array}$ & $\begin{array}{c}\mathrm{D} / \mathrm{R}_{\mathrm{p}}{ }^{2} \\
{\left[\mathrm{~s}^{-1}\right]}\end{array}$ \\
\hline 30.0 & 2.3 & $2.43 \times 10^{-4}$ \\
& 3.3 & $3.14 \times 10^{-4}$ \\
\hline 49.9 & 1.6 & $4.26 \times 10^{-4}$ \\
& 3.1 & $3.35 \times 10^{-4}$ \\
& 4.6 & $3.35 \times 10^{-4}$ \\
& 6.3 & $3.85 \times 10^{-4}$ \\
\hline 70.0 & 3.8 & $6.09 \times 10^{-4}$ \\
& 8.1 & $5.17 \times 10^{-4}$ \\
& 11.5 & $4.67 \times 10^{-4}$ \\
& 16.0 & $4.67 \times 10^{-4}$ \\
\hline
\end{tabular}




\section{Table 6}

Kinetic measurements of $\mathrm{H}_{2}$-treated Maxsorb III/ethanol pair.

\begin{tabular}{|c|c|c|}
\hline $\begin{array}{l}\mathrm{T}_{\text {ads, }} \\
{\left[{ }^{\circ} \mathrm{C}\right]}\end{array}$ & $\begin{array}{l}\text { Equilibrium Pressure, } \\
\qquad \mathrm{kPa}\end{array}$ & $\begin{array}{l}\mathrm{D} / \mathrm{R}_{\mathrm{p}}^{2} \\
{\left[\mathrm{~s}^{-1}\right]}\end{array}$ \\
\hline \multirow[t]{2}{*}{30.0} & 2.3 & $2.03 \times 10^{-4}$ \\
\hline & 3.4 & $2.54 \times 10^{-4}$ \\
\hline \multirow[t]{6}{*}{50.0} & 1.6 & $3.04 \times 10^{-4}$ \\
\hline & 3.1 & $2.43 \times 10^{-4}$ \\
\hline & 4.6 & $2.43 \times 10^{-4}$ \\
\hline & 6.3 & $2.43 \times 10^{-4}$ \\
\hline & 7.9 & $2.84 \times 10^{-4}$ \\
\hline & 9.4 & $3.04 \times 10^{-4}$ \\
\hline \multirow[t]{4}{*}{69.2} & 3.8 & $3.55 \times 10^{-4}$ \\
\hline & 7.9 & $3.55 \times 10^{-4}$ \\
\hline & 11.2 & $3.14 \times 10^{-4}$ \\
\hline & 15.5 & $3.04 \times 10^{-4}$ \\
\hline
\end{tabular}




\section{Table 7}

Parameters of Arrhenius equation of studied adsorbent/refrigerant pairs.

\begin{tabular}{lcc}
\hline Adsorbent/refrigerant pair & $\begin{array}{c}\mathbf{D}_{\mathbf{s o}} / \mathbf{R}_{\mathbf{p}}{ }^{2} \\
{\left[\mathbf{s}^{-1}\right]}\end{array}$ & $\begin{array}{c}\mathbf{E}_{\mathbf{a}} \\
{\left[\mathbf{k J} \mathbf{~ k g}^{-1}\right]}\end{array}$ \\
\hline Parent Maxsorb III/ethanol & $1.61 \times 10^{-2}$ & 234.5 \\
$\mathrm{KOH}-\mathrm{H}_{2}$ treated Maxsorb III/ethanol & $5.32 \times 10^{-2}$ & 300 \\
& & 171 \\
\hline
\end{tabular}

